\title{
Associations between dairy consumption and body weight: a review of the evidence and underlying mechanisms
}

\author{
Anestis Dougkas ${ }^{1}$, Christopher K. Reynolds ${ }^{2}$, Ian D. Givens ${ }^{1}$, Peter C. Elwood ${ }^{3}$ \\ and Anne M. Minihane ${ }^{4 *}$ \\ ${ }^{1}$ Nutritional Sciences Research Unit, School of Agriculture, Policy and Development, Faculty of Life Sciences, \\ University of Reading, Reading RGG GAR, UK \\ ${ }^{2}$ School of Agriculture, Policy and Development, Faculty of Life Sciences, University of Reading, Reading RG6 6AR, UK \\ ${ }^{3}$ Department of Epidemiology, Statistics and Public Health, Cardiff University, University Hospital of Wales, Heath Park, \\ Cardiff CF14 $4 X N$, UK \\ ${ }^{4}$ Department of Nutrition, Norwich Medical School, University of East Anglia (UEA), Norwich NR4 7TJ, UK
}

\begin{abstract}
As the incidence of obesity is reaching 'epidemic' proportions, there is currently widespread interest in the impact of dietary components on body-weight and food intake regulation. The majority of data available from both epidemiological and intervention studies provide evidence of a negative but modest association between milk and dairy product consumption and BMI and other measures of adiposity, with indications that higher intakes result in increased weight loss and lean tissue maintenance during energy restriction. The purported physiological and molecular mechanisms underlying the impact of dairy constituents on adiposity are incompletely understood but may include effects on lipolysis, lipogeneis and fatty acid absorption. Furthermore, accumulating evidence indicates an impact of dairy constituents, in particular whey protein derivatives, on appetite regulation and food intake. The present review summarises available data and provides an insight into the likely contribution of dairy foods to strategies aimed at appetite regulation, weight loss or the prevention of weight gain.
\end{abstract}

Key words: Dairy products: BMI: Obesity: Appetite: Calcium

\section{Introduction}

In addition to being a high-quality protein source, milk and dairy products represent important sources of $\mathrm{Ca}$, iodine, riboflavin and $\mathrm{B}_{12}$, providing $60,55,52$ and $150 \%$ of the adult reference nutrient intakes in the UK for these nutrients, respectively ${ }^{(1)}$. In recent years, attention has focused on the macronutrient composition of dairy products and the potential effects of dairy consumption on the risk of chronic diseases such as CVD, and more recently, obesity and its associated metabolic disorders such as the metabolic syndrome and type 2 diabetes. The present review specifically examines the evidence from epidemiological studies and intervention trials that have investigated the relationship between dairy product consumption and dietary $\mathrm{Ca}$, and measures of adiposity. Furthermore, potential mechanisms underlying the possible relationship between dairy constituents and body-weight regulation, and in particular appetite, are explored. The review commences by detailing current and predicted trends in obesity incidence, and worldwide consumption patterns of milk and other dairy products.

\section{Obesity prevalence and projections}

The prevalence of excess body weight has reached epidemic proportions, with more than 1.6 billion adults being overweight $\left(\mathrm{BMI} \geq 25 \mathrm{~kg} / \mathrm{m}^{2}\right)$ worldwide of which 400 million are clinically obese $\left(\mathrm{BMI} \geq 30 \mathrm{~kg} / \mathrm{m}^{2}\right)^{(2)}$. Table 1 illustrates the current and predicted future prevalence of overweight and obesity in various parts of the world. The UK obesity rates are the third highest in Europe, with the prevalence of overweight individuals (including obese) being $61.9 \%$ for females and $65.7 \%$ for males and $24.2 \%$ and $21 \cdot 6 \%$ classified as obese, respectively ${ }^{(3)}$.

Abbreviations: CCK, cholecystokinin; CLA, conjugated linoleic acid; GLP-1, glucagon-like peptide-1; 1,25(OH) $\mathrm{D}_{3}, 1,25$ dihydroxyvitamin $\mathrm{D}_{3}$; UCP2, uncoupling protein-2.

*Corresponding author: Dr Anne M. Minihane, email a.minihane@uea.ac.uk 
Table 1. Current and projected age-standardised estimates for overweight and obesity by country for both sexes, aged 15-100 years*

\begin{tabular}{|c|c|c|c|c|}
\hline \multirow{3}{*}{$\begin{array}{l}\text { BMI... } \\
\text { Country }\end{array}$} & \multicolumn{2}{|c|}{$\geq 25$ to $<30 \mathrm{~kg} / \mathrm{m}^{2}$} & \multicolumn{2}{|c|}{$\geq 30 \mathrm{~kg} / \mathrm{m}^{2}$} \\
\hline & 2005 & 2015 & 2005 & 2015 \\
\hline & $\begin{array}{c}\text { Prevalence } \\
(\%)\end{array}$ & $\begin{array}{c}\text { Predicted } \\
\text { prevalence } \\
(\%)\end{array}$ & $\begin{array}{c}\text { Prevalence } \\
(\%)\end{array}$ & $\begin{array}{c}\text { Predicted } \\
\text { prevalence } \\
(\%)\end{array}$ \\
\hline Argentina & $38 \cdot 2$ & 34.7 & $31 \cdot 2$ & $44 \cdot 1$ \\
\hline Australia & 43.1 & $44 \cdot 1$ & $24 \cdot 3$ & 33.4 \\
\hline Brazil & 37.0 & 39.3 & 13.5 & 24.1 \\
\hline Canada & 37.6 & 37.5 & 23.5 & $27 \cdot 8$ \\
\hline China & $27 \cdot 2$ & $40 \cdot 8$ & 1.7 & 7.6 \\
\hline Greece & $42 \cdot 4$ & 41.5 & $26 \cdot 1$ & $30 \cdot 6$ \\
\hline South Africa & $32 \cdot 3$ & 33.0 & $21 \cdot 0$ & 23.5 \\
\hline UK & $40 \cdot 9$ & $40 \cdot 6$ & $22 \cdot 9$ & $27 \cdot 1$ \\
\hline USA & 34.9 & 29.4 & 39.2 & 53.0 \\
\hline
\end{tabular}

${ }^{*}$ Calculated from data based on WHO factsheets ${ }^{(3)}$.

WHO projections suggest that by 2015, approximately 2.3 billion adults will be overweight and more than 700 million obese (Table 1). In the UK, it is projected that within this time frame, $67 \cdot 7 \%$ of adults will be overweight ${ }^{(3)}$.

\section{Dairy consumption patterns worldwide}

Per capita consumption of dairy products is generally higher in the majority of developed countries relative to less developed countries ${ }^{(4)}$. The average per capita consumption of dairy products in the European Union (twenty-five countries) is 92.6 litres for milk, $18.4 \mathrm{~kg}$ for cheese and $4.2 \mathrm{~kg}$ for butter per annum ${ }^{(5)}$. Comparable consumption patterns are evident in North America, with annual per capita consumption of 94.7 and 83.9 litres of milk, $12 \cdot 2$ and $16.0 \mathrm{~kg}$ of cheese and 3.3 and $2 \cdot 1 \mathrm{~kg}$ of butter in Canada and the USA, respectively ${ }^{(5)}$. The most recent estimates of dairy product consumption in the UK from the Department for Environment, Food and Rural Affairs' Family Food Survey in 2008 indicate that total milk consumption has decreased by $15 \%$ whilst yoghurt and cheese have increased by 34 and $10 \%$ during the last decade ${ }^{(6)}$. Comparable changes in dairy consumption patterns are evident throughout the European Union and North America ${ }^{(7-9)}$.

Although dairy products undoubtedly represent the major source of dietary $\mathrm{Ca}$, there is recognition that for a subgroup of individuals dietary supplements make a significant contribution to their total intake, although at a population level the contribution is likely to be relatively minor. For example, in a 2009 report detailing supplement use in nine European countries dietary supplements were reported to contribute $0 \cdot 1-5 \cdot 1 \%$ and $1 \cdot 3-8 \cdot 5 \%$ of total intake in male and female adults, respectively ${ }^{(10)}$. In reality this may be an overestimation, with many individuals purchasing supplements but consuming them on an infrequent basis.
Scope of the review and an overview of the strengths and limitations of available evidence

The association between dairy product/Ca consumption and body weight regulation has been widely investigated with data from epidemiological and intervention studies in both adults and children summarised in numerous recent reviews ${ }^{(11-22)}$. In a number of studies reporting on the association between dietary $\mathrm{Ca}$ and adiposity and its regulation, no distinction is made between dairy and non-dairy $\mathrm{Ca}$ sources, making it difficult to establish whether the beneficial component is likely to be $\mathrm{Ca}$ or an alternative milk bioactive component whose intake is highly correlated with total Ca intake.

To our knowledge, no recent review has examined the impact of dairy products on both body composition and appetite, which represents the primary focus of the present review. Relevant articles were abstracted through the PubMed database, Google Scholar, and the cited references of these reports using the following key words: 'dairy', 'milk', 'BMI', 'weight', 'body composition', 'appetite', 'satiety' and 'calcium'. These key words produced 4716 hits Articles available only in abstract form or not published in English were excluded. Studies conducted in children and adolescents were not included in the present review. All observational or intervention studies which exclusively examined the impact of $\mathrm{Ca}$ supplements were not reviewed since the focus is dairy products and not $\mathrm{Ca}$ per se. However, where a direct comparison between the impact of dietary or dairy $\mathrm{Ca}$ and supplemental $\mathrm{Ca}$ is made the data are included, as it provides a valuable insight into the potential bioactive components in dairy products. Using these criteria a total of 118 articles, which examined the impact of milk, milk products, or dietary $\mathrm{Ca}$ (which is mainly derived from dairy sources) on adiposity and its regulation in adults, were considered. This number does not include the mechanistic studies in cells or animals that are mentioned in the mechanistic section of the present review.

The initial evidence to indicate an association between dairy consumption was derived from cross-sectional studies. However, it is recognised that this type of study design is receptive to inverse causation bias, meaning that the presence of adiposity in individuals may affect dairy consumption habits. Prospective studies represent a more robust design. Unless otherwise stated in the text, it is assumed that the associations between dairy and adiposity cited in the text have been adjusted for the main confounding factors such as age, sex, physical activity, smoking status, alcohol consumption, fibre intake and energy intake. The validity of the adjustment of association models for total energy intake needs to be carefully considered when interpreting study results and conducting cross-study comparisons. Given the high degree of correlation between total energy intake and adiposity, adjustment for total energy intake appears 
appropriate $^{(23)}$. However, given that the beneficial impact of dairy constituents may be through an impact on appetite and food intake and therefore energy regulation, the adjustment for total energy intake may be misleading due to correction of the model for the mediator of the effect. Yet, the majority of the cross-sectional and prospective studies adjust their models for energy intake.

Intervention trials represent the most 'robust' source of data and are the most appropriate to support a causeeffect relationship.

In addition to reviewing the published literature, the present review includes a novel meta-analysis of eighteen epidemiological studies, in an attempt to summarise the relationship between dietary $\mathrm{Ca}$ intake and BMI, after correction for trial effects. Further details of the data analysis methods employed and the selection criteria for the inclusion or exclusion of individual studies are given later.

Throughout the text ' $\mathrm{Ca}$ ' or 'total $\mathrm{Ca}$ ' refers to both 'dietary $\mathrm{Ca}$ ' (Ca derived solely from the total diet) and $\mathrm{Ca}$ consumed as supplements, whilst 'dairy Ca' refers to the Ca derived solely from dairy product consumption.

\section{Epidemiological evidence of the effects of dairy product consumption on body composition}

\section{Evidence from cross-sectional studies}

Several cross-sectional studies have indicated an inverse relationship between dairy consumption and body weight (Table 2). Mirmiran et al. ${ }^{(24)}$ showed that the number of dairy servings was inversely correlated with BMI $(r-0.38 ; P<0.05)$ (Fig. 1) ${ }^{(24)}$. Similar results were observed by Varenna et al. ${ }^{(25)}$ in early postmenopausal women. However, no association was observed in lean young Japanese women with low mean habitual dairy consumption ( $40 \mathrm{~g}$ dairy products $/ 1000 \mathrm{~kJ})^{(26)}$, and a low mean BMI $\left(20.8 \mathrm{~kg} / \mathrm{m}^{2}\right)$, which is suggestive of a possible threshold level for either body weight or dairy consumption below which no associations are observed.

Two studies have also examined the relationship between dairy product consumption and the prevalence of central obesity. Azadbakht et al. ${ }^{(27)}$ showed that dairy consumption is inversely associated with the prevalence of an enlarged waist circumference (defined as $>102 \mathrm{~cm}$ in men and $>88 \mathrm{~cm}$ in women), with OR by quartile of 1, 0.89, 0.74 and $0.63(P<0.001)$ (Fig. 1), with a more recent study from the same group confirming the earlier associations between dairy and central adiposity ${ }^{(28)}$.

A limited number of studies have examined the impact of 'type' of dairy product on the associations between dairy consumption and body composition. However, some inter-study inconsistencies in the findings are evident. Two studies, which observed no overall association between total dairy consumption and adiposity, reported that low-fat dairy consumption was either positively associated with BMI and waist circumference ${ }^{(29)}$ or was inversely associated with waist-to-hip ratio ${ }^{(30)}$. In the studies of Snijder et al. $^{(29)}$ and Beydoun et al. ${ }^{(31)}$ cheese was positively associated with the prevalence of obesity and central obesity. In contrast, milk and yoghurt were negatively related to adiposity in Beydoun's analysis, while in Snijder's study there were no significant inverse associations (Table 2). However, both authors do state that due to the fact that obese individuals often consume low-fat dairy products in an attempt to lose weight, cause-effect relationships are often difficult to explore in cross-sectional studies. Marques-Vidal et al ${ }^{(32)}$ observed a modest but significant negative relationship between milk intake and BMI in men $(r-0.10 ; P<0.001)$ and women ( $r-0.04 ; P<0.001)$, which is consistent with the findings of Dicker et al. ${ }^{(33)}$. In contrast, Lawlor et al. ${ }^{(34)}$ reported that $2 \cdot 8 \%$ of the 4024 women who reported never drinking milk had a lower BMI than those who drank milk. However, this subgroup probably includes lactose-intolerant women and it is not representative of any meaningful group within the general population. Therefore, overall, the cross-sectional data suggest that 'lower'-fat dairy products such as milk and yoghurt are associated with lower adiposity, with cheese having the opposite effect.

As far as $\mathrm{Ca}$ is concerned, numerous studies have showed inverse associations between dietary $\mathrm{Ca}$, and the prevalence of obesity ${ }^{(33,35-39)}$, central adiposity ${ }^{(28)}$, body weight $^{(40,41)}$ and sagittal abdominal diameter ${ }^{(42)}$. To date, seven studies have evaluated the association of dietary Ca with adiposity according to sex or ethnicity ${ }^{(43-49)}$, with stronger associations evident in females relative to males and in white women compared with black women ${ }^{(43,44,49)}$. However, due to the numerous differences in the diet and overall lifestyles between men and women and ethnic groups, the results regarding the impact of sex and race on $\mathrm{Ca}$-adiposity associations remain controversial.

\section{Evidence from baseline data in prospective studies examined in a cross-sectional manner}

Baseline data of cohorts from several prospective studies with CVD, hypertension or type 2 diabetes incidence as primary outcomes were used to examine associations between dairy consumption and body composition (mainly BMI $^{(50-57)}$. Often, as adiposity measures did not represent a primary outcome, these analyses have not controlled for important confounding factors including energy intake. However, their distinct strength is the size of the cohort, ranging in size from 2245 to 110792 participants. The results from studies that examined dairy consumption, dietary $\mathrm{Ca}$ and total $\mathrm{Ca}$ are summarised separately below. Briefly, among seven studies that examined dairy consumption ${ }^{(27,55,56,58-61)}$, two studies ${ }^{(27,58)}$ showed a statistically significant negative association and one study ${ }^{(61)}$ showed a positive association between increased dairy consumption and BMI as demonstrated in Fig. 2. 
Table 2. Cross-sectional studies of dairy consumption and measures of adiposity

\begin{tabular}{|c|c|c|c|}
\hline Study & Study details & Results and conclusion & Adjustments \\
\hline Mirmiran et al. (2005) ${ }^{(24) \star}$ & $\begin{array}{l}\text { The Tehran Lipid and Glucose } \\
\text { Study, } 223 \text { men, } 239 \text { women } \\
\text { (aged }>16 \text { years) }\end{array}$ & $\begin{array}{l}\text { A significant inverse relationship between } \mathrm{BMI} \text { and servings } \\
\text { of dairy consumption per } \mathrm{d} \text {. OR for being overweight were } 0.78 \\
(95 \% \mathrm{Cl} 0.43,0.92) \text { and } 0.89(95 \% \mathrm{Cl} 0.53,0.95) \text { for men and } \\
\text { women, respectively, with equivalent OR for obesity of } 0.73 \\
(95 \% \mathrm{Cl} 0.40,0.83) \text { and } 0.69(95 \% \mathrm{Cl} 0.34,0.80) \text {, respectively, } \\
\text { when comparing Q1 and Q4 }\end{array}$ & $\begin{array}{l}\text { Age, intake of total energy, carbohydrate, fat, } \\
\text { protein, dietary fibre and physical activity }\end{array}$ \\
\hline Varenna et al. $(2007)^{(25) \star}$ & $\begin{array}{l}1771 \text { early-postmenopausal } \\
\text { Italian women }\end{array}$ & $\begin{array}{l}\text { An inverse relationship between dairy intake and BMI (Q1, } \\
\left.\text { BMI } 24.1(\text { SD } 3.4) \mathrm{kg} / \mathrm{m}^{2} v \text {. Q4, } 23.2(\mathrm{SD} 3.4) \mathrm{kg} / \mathrm{m}^{2} ; P=0.001\right)\end{array}$ & Age, age at menopause, smoking \\
\hline Murakami et al. (2006) ${ }^{(26)}$ & $\begin{array}{l}1905 \text { Japanese women } \\
\text { (aged 18-20 years) }\end{array}$ & No significant relationship between $\mathrm{BMI}$ and dairy consumption & $\begin{array}{l}\text { Residential block size of residential area, smoking, } \\
\text { alcohol, physical activity, experience of dieting, } \\
\text { intentional dietary change, rate of eating, } \\
\text { protein, fat and dietary fibre intake }\end{array}$ \\
\hline Azadbakht et al. $(2005)^{(27) *}$ & $\begin{array}{l}375 \text { men and } 470 \text { Tehranian } \\
\text { women (aged } 18-74 \text { years) }\end{array}$ & $\begin{array}{l}\text { A significant inverse relationship between dairy consumption } \\
\text { and WC (OR by quartile: } 1,0.89,0.74,0.63 ; P<0.001 \text { ) }\end{array}$ & $\begin{array}{l}\text { Age, total energy, percentage of energy from fat, } \\
\text { BMI, use of blood pressure and oestrogen } \\
\text { medication, smoking and physical activity }\end{array}$ \\
\hline $\begin{array}{l}\text { Azadbakht \& Esmaillzadeh } \\
(2008)^{(28) \star}\end{array}$ & $\begin{array}{l}926 \text { Tehranian women } \\
\text { (aged } 40-60 \text { years) }\end{array}$ & $\begin{array}{l}\text { Dairy consumption was negatively associated with WHR } \\
\qquad(r-0.2 ; P<0.05)\end{array}$ & $\begin{array}{l}\text { Age, physical activity, depression, smoking, } \\
\text { coffee consumption, menopausal status, } \\
\text { marriage, parity, age, medication use and BMI }\end{array}$ \\
\hline Snijder et al. $(2007)^{(29) *}$ & $\begin{array}{l}\text { The Hoorn Study, } 852 \text { men } \\
\text { and } 1044 \text { Dutch women } \\
\text { (aged } 50-75 \text { years) }\end{array}$ & 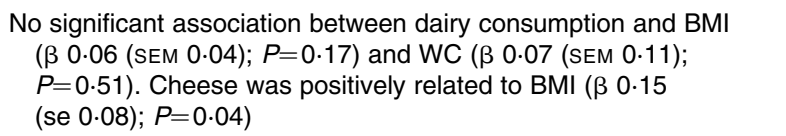 & $\begin{array}{l}\text { Age, sex, total energy intake, fibre, physical } \\
\text { activity, alcohol, smoking status, income, } \\
\text { educational level and antihypertensive } \\
\text { medication use }\end{array}$ \\
\hline Brooks et al. $(2006)^{(30) *}$ & $\begin{array}{l}\text { The Bogalusa Heart Study, } \\
505 \text { men, } 801 \text { women } \\
\text { (aged } 20-38 \text { years) }\end{array}$ & $\begin{array}{l}\text { No significant relationship between dairy consumption and BMI } \\
\text { or WHR. Significant negative relationship between low-fat dairy } \\
\text { consumption and abdominal obesity in white males }(P=0.008)\end{array}$ & $\begin{array}{l}\text { Energy intake, age, physical activity outside } \\
\text { of work }\end{array}$ \\
\hline Beydoun et al. $(2008)^{(31)}$ & $\begin{array}{l}7652 \text { women and } 6966 \text { US } \\
\text { men (aged }>18 \text { years) }\end{array}$ & $\begin{array}{l}\text { Each serving of cheese was associated with a higher prevalence } \\
\text { of obesity (OR } 1.14 ; 95 \% \mathrm{Cl} 1.08,1.21) \text { and central obesity } \\
\text { (OR } 1.11 ; 95 \% \mathrm{Cl} 1.05,1.17) \text { while each serving of yoghurt was }\end{array}$ & $\begin{array}{l}\text { Age, sex, ethnicity, socio-economic status } \\
\text { (education and poverty income ratio), } \\
\text { energy intake and physical activity }\end{array}$ \\
\hline
\end{tabular}

Marques-Vidal et al. (2006) ${ }^{(32) \star} \quad$ The Portuguese Health Interview Survey, 17771 men, 19742 women (aged $\geq 18$ years)

Dicker et al. (2008) $)^{(33)}$

Lawlor et al. $(2005)^{(34) \star}$

Rosell et al. (2004) ${ }^{(42)}$
The Israeli National Health and Nutrition Survey, 1371 men, 1411 women (aged 25-64 years)

The British Women's Heart and Health Study, 4024 women (aged 60-79 years)

301 Swedish men (aged 63 years) inversely related to obesity (OR $0.51 ; 95 \% \mathrm{Cl} 0.36,0.71$ ) and central obesity (OR 0.51; $95 \% \mathrm{Cl} 0.37,0.70$ )

A significantly inverse relationship between $\mathrm{BMl}$ and milk consumption (men: $r-0.11, P<0.001$; women: $r-0.06$ $P<0.001$ ), with the strongest relationships in men and premenopausal women

Daily milk consumption was higher in normal-weight subjects (103.4 (SD 147.5) g) compared with overweight (85.7 (SD 122.3) g) and obese subjects $(84.5$ (SD 135.1) g) $(P<0.01)$

Milk drinkers had higher BMl compared with non-milk drinkers (BMI 27.6 and $26.4 \mathrm{~kg} / \mathrm{m}^{2}$, respectively; $P=0.03$ )

An inverse relationship between dairy fat consumption and SAD in under-reporters $(r-0.36 ; P=0.001)$ and not in non-under-reporters $(r-0.04 ; P=0.59)$
Age, number of meals, smoking, educational level, usual activity at work and leisure time physical activity

\section{Not stated}

Age

Not stated 


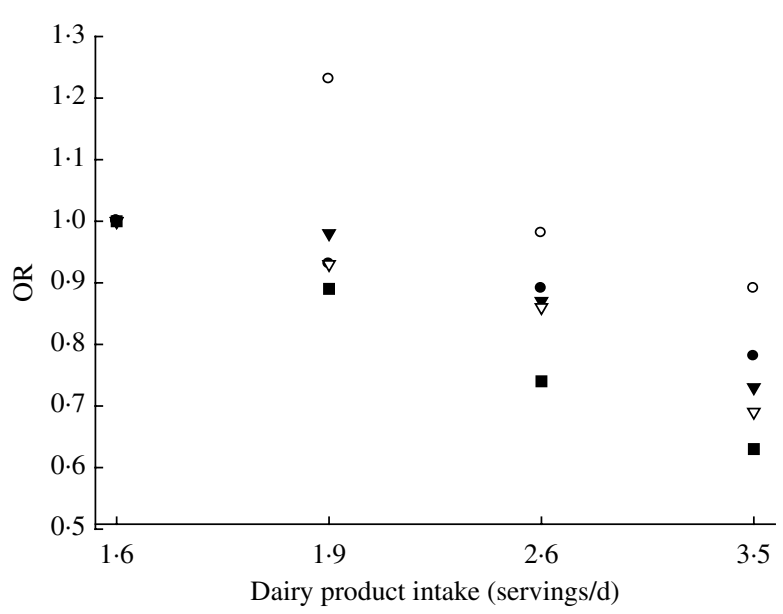

Fig. 1. Risk for being overweight, obese and having an enlarged waist circumference in relation to the daily intake of dairy products. (๑), Men OR for being overweight ${ }^{(24)} ;(O)$, women OR for being overweight ${ }^{(24)} ;(\boldsymbol{\nabla})$, men OR for being obese ${ }^{(24)} ;(\nabla)$, women OR for being obese ${ }^{(24)} ;(\boldsymbol{\square})$, OR for enlarged waist circumference.

Among six studies that examined dietary $\mathrm{Ca}^{(51,57,62-65)}$, four showed a negative association with BMI, with the difference between the highest and lowest dietary Ca consumption being $-0.3 \mathrm{~kg} / \mathrm{m}^{2}(P<0.01)^{(62)},-0.6 \mathrm{~kg} / \mathrm{m}^{2(51)}$, $-0.8 \mathrm{~kg} / \mathrm{m}^{2}(P<0.001)^{(57)}$ and $-1.3 \mathrm{~kg} / \mathrm{m}^{2}(P<0.001)^{(65)}$. One study showed no difference ${ }^{(64)}$ and one ${ }^{(63)}$, which observed no overall group effect, reported an effect of sex with men having higher $\left(+0 \cdot 2 \mathrm{~kg} / \mathrm{m}^{2}\right)$ and women lower $\left(-0.3 \mathrm{~kg} / \mathrm{m}^{2}\right)$ BMI between quintile $5 v$. quintile 1 of dietary $\mathrm{Ca}$ intakes without the level of significance being reported. Finally, two studies ${ }^{(52,66)}$ also showed a negative association between total $\mathrm{Ca}$ intake and BMI (with differences between quintile $5 v$. quintile 1 of
$-1.0 \mathrm{~kg} / \mathrm{m}^{2}$ in the Iowa Women's Health study ${ }^{(51)}$ and $-0.2 \mathrm{~kg} / \mathrm{m}^{2} \quad(P<0.001)$ in the Health Professionals Follow-up Study $\left.{ }^{(66)}\right)$.

Only two studies have examined associations between milk consumption and BMI, with a significant negative association found in the Caerphilly study $(P<0.001)^{(54)}$, whilst no significant difference $(P=0 \cdot 50)$ was observed in a prospective study by Ness et al. ${ }^{(50)}$.

In conclusion, there are inconsistent results from the baseline data of prospective studies examined in a cross-sectional manner regarding the relationship between dairy product consumption and BMI. This inconsistency might be due to the fact that the data analysis conducted has often not controlled for energy intake, therefore masking the potential impact of dairy consumption on adiposity.

\section{Evidence from prospective studies}

A number of prospective studies have observed that regular dairy consumption is inversely associated with weight gain and abdominal obesity (Table 3$)^{(67-71)}$. For instance, results of The Coronary Artery Risk Development In Adults (CARDIA) 10-year study ${ }^{(70)}$ showed a $19.7 \%$ lower incidence of obesity between quintile 5 (intake frequency $\geq 35$ times/week) and quintile 1 ( 0 to $<10$ times/week) of dairy intake (milk, cheese, sour cream, cream and yoghurt) in adults with a BMI $\geq 25 \mathrm{~kg} / \mathrm{m}^{2}$ at baseline.

Two studies have specifically evaluated the association between changes in consumption of dairy products and long-term weight gain (9-12 years) ${ }^{(72,73)}$. Rosell et al. ${ }^{(73)}$ analysed a cohort of middle-aged perimenopausal

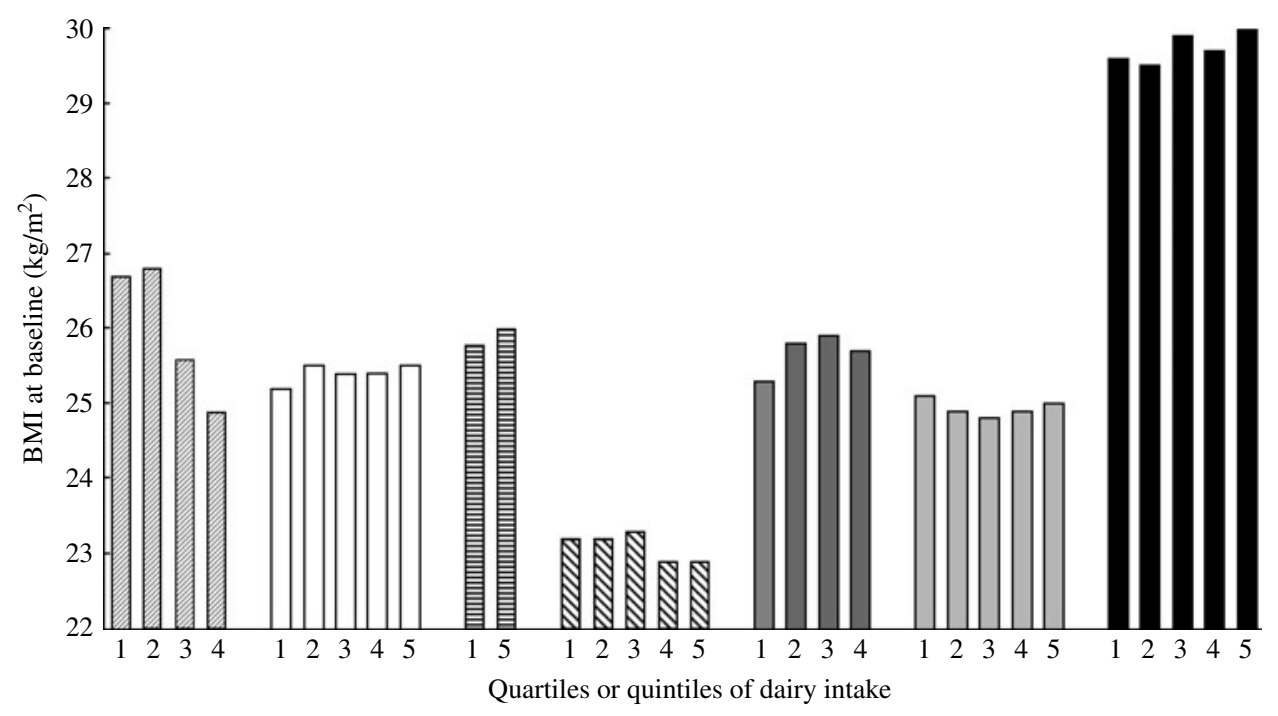

Fig. 2. The association between BMI and dairy consumption, with the data derived from cross-sectional analysis of available baseline data from large prospective cohorts. (四), Azadbakht et al. ${ }^{(27)}$ : The Tehran Lipid and Glucose Study; $-1.8 \mathrm{~kg} / \mathrm{m}^{2}(P<0.01)$. ( $\left.\square\right)$, Choi et al. ${ }^{(56)}$ : The Health Professionals Follow-up Study; $+0.3 \mathrm{~kg} / \mathrm{m}^{2}$. (目), Liu et al. ${ }^{(55)}$ : The Women's Health Study; $+0.2 \mathrm{~kg} / \mathrm{m}^{2}$. ( $\left.\mathbb{\mathbb { Q }}\right)$, Alonso et al. ${ }^{(58)}$ : The University of Navarra Follow-up Study; $-0.3 \mathrm{~kg} / \mathrm{m}^{2}(P=0.01)$.

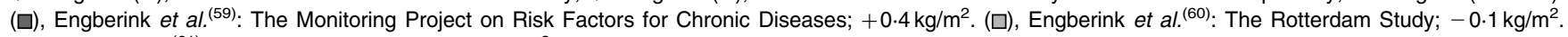
$(\square)$, Toledo et al. ${ }^{(61)}$ : The PREDIMED study; $+0.4 \mathrm{~kg} / \mathrm{m}^{2}(P=0.04)$. 
Table 3. Prospective studies of dairy consumption and body composition

\begin{tabular}{|c|c|c|c|}
\hline Authors & Details & Results and conclusion & Adjustments \\
\hline Newby et al. $(2003)^{(67,68) *}$ & $\begin{array}{l}\text { The Baltimore Longitudinal Study of Aging; } \\
219 \text { women, } 240 \text { men (aged } 30-80 \text { years), } \\
\text { 14-year follow-up }\end{array}$ & $\begin{array}{l}\text { A dietary pattern rich in low-fat dairy products and } \\
\text { high-fibre foods was associated with a smaller } \\
\text { increase in BMI and waist circumference }(P<0.05)\end{array}$ & Age and sex \\
\hline Drapeau et al. $(2004)^{(69)}$ & $\begin{array}{l}\text { The Québec Family Study; } 136 \text { women and } \\
112 \text { men ( } \geq 18 \text { years), 6-year follow-up }\end{array}$ & $\begin{array}{l}\text { A dietary pattern rich in whole fruit, skimmed and } \\
\text { partly skimmed milk was associated with less } \\
\text { body-weight gain and adiposity ( } \beta-0.20 \\
\text { (SE } 0.09) ; P=0.06 \text { ) }\end{array}$ & Age and baseline body-weight indicators \\
\hline Pereira et al. $(2002)^{(70)}$ & $\begin{array}{l}\text { The CARDIA study; } 3157 \text { men } \\
\text { (aged 18-30 years), 10-year follow-up }\end{array}$ & $\begin{array}{l}\text { There was a } 19.7 \% \text { reduction in incidence of obesity } \\
\text { between quintile } 5 \text { and } 1 \text { of dairy consumption in } \\
\text { adults with } \mathrm{BMI} \geq 25 \mathrm{~kg} / \mathrm{m}^{2} \text { at baseline }(P<0.001)\end{array}$ & $\begin{array}{l}\text { Age, sex, race, energy intake, study centre and } \\
\text { baseline BMI }\end{array}$ \\
\hline Rajpathak et al. (2006) $)^{(72) *}$ & $\begin{array}{l}\text { The Health Professionals Follow-Up Study; } \\
19615 \text { men (aged } 40-75 \text { years), } \\
\text { 12-year follow-up }\end{array}$ & $\begin{array}{l}\text { Dairy consumption is not related to lower long-term } \\
\text { weight gain in men }\end{array}$ & $\begin{array}{l}\text { Age, baseline weight, smoking, alcohol intake, } \\
\text { physical activity, glycaemic load, and intakes } \\
\text { of energy, total fat, cereal fibre, whole grains, } \\
\text { fruit and vegetables, caffeine, trans-fat, and } \\
\text { low- and high-energy soft drinks }\end{array}$ \\
\hline Rosell et al. $(2006)^{(73) *}$ & $\begin{array}{l}19352 \text { perimenopausal women } \\
\text { (aged } 44-55 \text { years), 9-year follow-up }\end{array}$ & $\begin{array}{l}\text { Differences in subjects' BMI and type of dairy product } \\
\text { influence the association between weight change } \\
\text { and dairy consumption }\end{array}$ & $\begin{array}{l}\text { Age, baseline height and weight, education, parity, } \\
\text { intakes at baseline of energy, fat, carbohydrate, } \\
\text { protein, fibre and alcohol, the absolute change } \\
\text { in intakes of these nutrients during follow-up } \\
\text { (quartiles), and the studied categories of } \\
\text { change in intake of the other four dairy products } \\
\text { presented in the table }\end{array}$ \\
\hline Vergnaud et al. $(2008)^{(74) \star}$ & $\begin{array}{l}\text { The SU.VI.MAX Study; } 1245 \text { men and } \\
1022 \text { women (aged }>45 \text { years), } \\
\text { 6-year follow-up }\end{array}$ & $\begin{array}{l}\text { Milk }(P<0.05) \text { and yoghurt }(P<0.05) \text { were inversely } \\
\text { associated with } 6 \text {-year weight and WC changes } \\
\text { in OW only men. Milk }(P=0.08) \text { was positively } \\
\text { associated with WC changes in OW women. }\end{array}$ & $\begin{array}{l}\text { Age, intervention group, baseline value of the } \\
\text { outcome, educational level, smoking, physical } \\
\text { activity, alcohol, energy intakes and mean } \\
\text { adequacy ratio }\end{array}$ \\
\hline Snijder et al. $(2008)^{(75) *}$ & $\begin{array}{l}\text { The Hoorn Study; } 1124 \text { subjects } \\
\text { (aged 50-75 years), } 6 \cdot 4 \text { year change } \\
\text { in weight }\end{array}$ & $\begin{array}{l}\text { Higher dairy consumption was not associated with } \\
\text { changed in body weight, fat distribution or other } \\
\text { components of the metabolic syndrome }(P>0.05)\end{array}$ & $\begin{array}{l}\text { Age and sex, total energy intake, baseline value } \\
\text { of the outcome, alcohol intake, smoking and } \\
\text { physical activity }\end{array}$ \\
\hline
\end{tabular}

CARDIA, Coronary Artery Risk Development In Adults; SU.VI.MAX, SUpplémentation en VItamines et Minéraux AntioXydants; WC, waist circumference; OW, overweight.

* Studies used post hoc analysis. 
women and reported that the type of dairy product and the subject's BMI at baseline influenced the association between dairy consumption and body weight and abdominal obesity. Women with a constant $\geq$ one serving/d of cheese and whole/sour milk consumption had a lower risk of gaining $\geq 1 \mathrm{~kg}$ /year over 9 years, compared with those with an intake of $<$ one serving per $d$ (for cheese OR $0.85(95 \%$ CI $0.73,0.99)$ and for whole/sour milk OR $0.70(95 \%$ CI $0.59,0.84))^{(73)}$. When the analysis was conducted based on BMI status, only normal-weight women with a constant $\geq$ one serving/d of cheese and whole/sour milk consumption had lower risk of gaining $\geq 1 \mathrm{~kg} /$ year over 9 years. Vergnaud et al. ${ }^{(74)}$ showed inverse relationships between milk and yoghurt intake and body weight only in overweight men. Two studies also showed that baseline dairy consumption was not related to weight gain during 6.4 years and 12 years $^{(72,75)}$. However, after stratification by BMI, Snijder et al. ${ }^{(75)}$ showed that higher dairy consumption was significantly associated with an increase in BMI, waist and weight only in normal-weight subjects. Therefore, overall, three prospective studies ${ }^{(70,74,75)}$ showed that overweight and obese subjects could benefit more regarding body-weight regulation with dairy consumption.

Regarding dietary $\mathrm{Ca}$, results of a 23-year prospective study ${ }^{(76)}$ indicated no association between dietary Ca intake and BMI. As the authors stated, in this cohort this may be due to the high average intake of dietary $\mathrm{Ca}$ in the Dutch population, suggesting a threshold of $\mathrm{Ca}$ intake of approximately $800 \mathrm{mg} / \mathrm{d}$ above which no further benefit is observed. Other studies have suggested a threshold of $500-600 \mathrm{mg} / \mathrm{d}^{(20)}$ and $600-700 \mathrm{mg} / \mathrm{d}^{(29,47,77)}$. A number of prospective studies ${ }^{(72,74,75)}$ also failed to show an inverse association between a wide range of dietary $\mathrm{Ca}$ intakes and body composition, even when further analysis is conducted in subjects that consumed below the suggested threshold of $700 \mathrm{mg} \mathrm{Ca} / \mathrm{d}$. These data support the hypothesis that the observed associations appear to be specific to dairy sources and that dairy components other than Ca may be responsible as highlighted in the next section.

\section{Meta-analysis using the epidemiological evidence}

A mixed-model regression analysis was conducted using mean data reported in the above epidemiological studies in an attempt to summarise the relationship between dietary $\mathrm{Ca}$ intake and BMI after correction for trial effects ${ }^{(78)}$. The advantage of this methodology compared with simple regression models is that it corrects the relationship between BMI and the fixed effect of dietary Ca intake for random effects of individual trials. Generally, there are differences in measurement methods, in experimental units, in observations and in the accuracy of measurement across the studies. Thus, adjusting the regression for the trial effect reduces type II error and the bias in the estimation of the intercept and slope ${ }^{(78)}$.

Studies were selected based on the following criteria: (a) prospective and cross-sectional studies which examined the association between dairy products or dietary $\mathrm{Ca}$ and BMI; (b) included cohorts where data are presented as quartiles or quintiles of either dairy products or dietary $\mathrm{Ca}$. Due to the different methods of presenting the results and different definitions of the serving portions of dairy products among the studies it was impossible to transform all the available data into meaningful forms of accurate estimation of dairy product consumption. Thus, despite the fact that the focus of the review was dairy products and not $\mathrm{Ca}$, dietary $\mathrm{Ca}$ was the only accurate measurement of dairy intake.

A total of twenty-five studies were identified, with four ${ }^{(43,52,66,72)}$ excluded on the basis of reporting intakes of total $\mathrm{Ca}$ (both dietary and supplemental $\mathrm{Ca}$ in combination) and three ${ }^{(39,56,61)}$ on the basis that data on dairy, but not $\mathrm{Ca}$ intake, were published. Thus, in the final model eighteen studies were included (Fig. 3). There were no significant effects of sex or type of study (prospective or cross-sectional) on the relationship between $\mathrm{Ca}$ intake and BMI. The relationship between the 'adjusted BMI' and dietary $\mathrm{Ca}$ intake for the eighteen trials is presented in Fig. 3 with an overall linear regression equation of:

$$
\begin{gathered}
\text { Predicted BMI }=26 \cdot 0+(-0.00111 \times \text { mean Ca } \\
\text { intake }) \mathrm{kg} / \mathrm{m}^{2}(P=0.004) .
\end{gathered}
$$

Based on this equation, at $400 \mathrm{mg} \mathrm{Ca} / \mathrm{d}$ (low dietary $\mathrm{Ca}$ intake), a BMI of $25.6 \mathrm{~kg} / \mathrm{m}^{2}$ is predicted, while for $1200 \mathrm{mg} / \mathrm{d}$ a BMI of $24.7 \mathrm{~kg} / \mathrm{m}^{2}$ is predicted. In other words, an increase in Ca intake of $800 \mathrm{mg} / \mathrm{d}$ is associated with a decrease in BMI of $1 \cdot 1 \mathrm{~kg} / \mathrm{m}^{2}$.

Similar results were obtained when in the above model of the eighteen studies (Fig. 3) the four studies that examined both dietary and supplemental $\mathrm{Ca}$ in combination were also included (data not shown). When only the four studies ${ }^{(43,52,66,72)}$ that used total Ca (both dietary and supplemental $\mathrm{Ca}$ ) were analysed, the relationship between $\mathrm{Ca}$ and BMI was not significant $(P=0.65)$, which highlights the influence of different $\mathrm{Ca}$ forms. There is no doubt that dietary $\mathrm{Ca}$ intake is not equivalent to dairy consumption, although both are closely related, and dairy products still remain the major source of dietary Ca. However, other components in dairy products could play a beneficial role in body-weight regulation, as discussed later.

\section{Evidence from intervention trials of the effects of dairy product consumption on body composition}

There have been relatively few randomised intervention trials examining the effect of dairy products on body weight and other measures of adiposity, and generally 


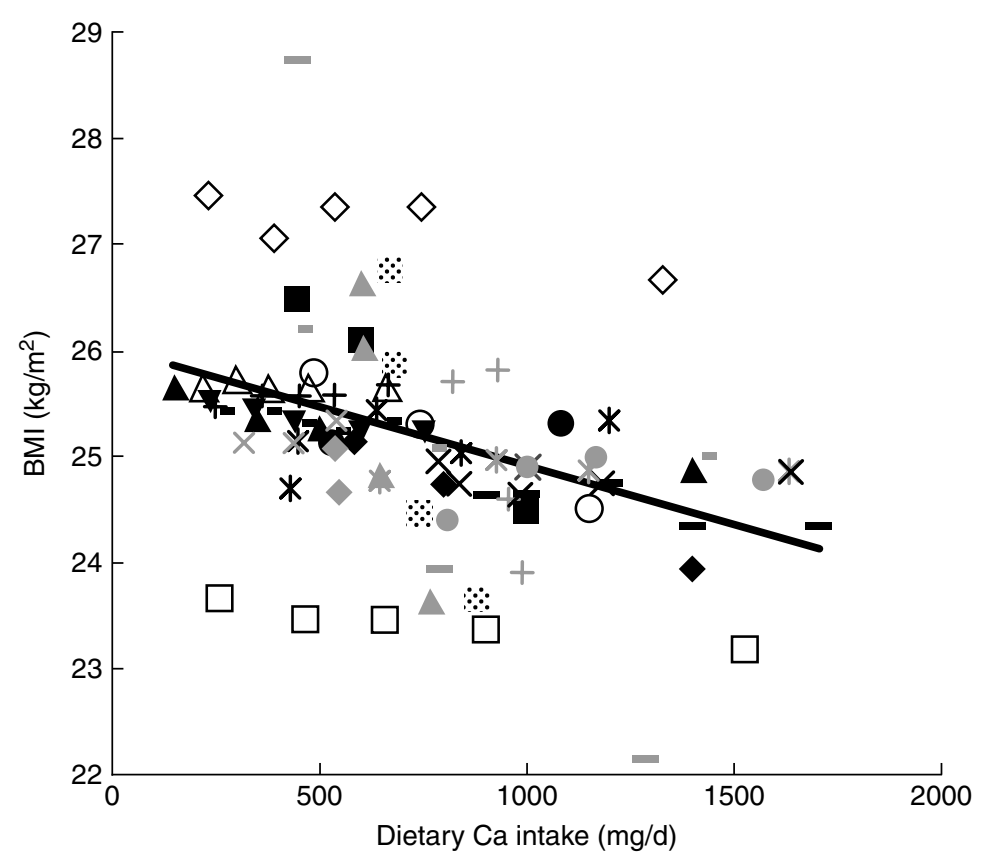

Fig. 3. Data derived from cross-sectional analysis of baseline data from eighteen large prospective cohorts showing the association between BMI and total dietary $\mathrm{Ca}$ intake adjusted for trial effects excluding the trials that reported only milk consumption. ( $\bullet)$, Van der Vijver et al. ${ }^{(51)}$, men; (ם), Van der Vijver et al. ${ }^{(51)}$, women;

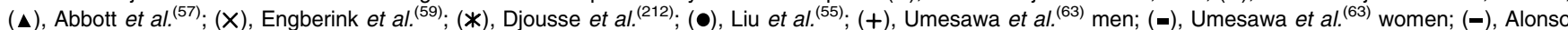
et al. ${ }^{(58)} ;(\diamond)$, Wang et al. ${ }^{(213)} ;(\bullet)$, Mirmiran et al. ${ }^{(24)}$ men; $(\Delta)$, Mirmiran et al. ${ }^{(24)}$ women; $(\times)$, Murakami et al. ${ }^{(26)} ;(*)$, Snijder et al. ${ }^{(29)} ;(0)$, Liu et al. ${ }^{(65)}$,

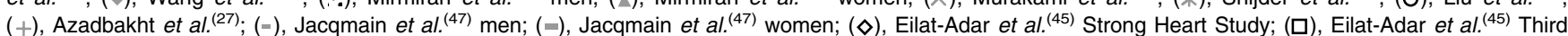
National Health and Nutrition Examination Survey; $(\Delta)$, Van Dam et al. ${ }^{(64)}$; (๑), Engberink et al. ${ }^{(60)}$; ( $)$, Umesawa et al. ${ }^{(62)}$; (-), linear (overall), $y=-0.001 x+26.01(P=0.004)$.

bone health or blood pressure, rather than adiposity, has represented the primary outcome. Although the published studies differ greatly in many aspects of study design (length of intervention, type of dairy product introduced), they all had a parallel rather than cross-over intervention approach. The order that the trials are discussed in the present review is based on energy intake, with the clinical trials without and with energy restriction presented separately.

\section{Evidence from intervention trials without energy} restriction

Numerous studies have been conducted in adults without energy restriction ${ }^{(79-88)}$ and with body composition being the primary endpoint of six studies ${ }^{(79,86-90)}$. Only two trials showed weight gain ${ }^{(79,80)}$. Barr et al. ${ }^{(79)}$ showed that both women and men who were in the increased milk group gained body weight $(0.6 \mathrm{~kg}$ and $0.5 \mathrm{~kg}$, respectively; $P<0 \cdot 01)$. However, the increase in weight was less than predicted $(2.5 \mathrm{~kg})$ from the $1046 \mathrm{~kJ} / \mathrm{d}$ added energy of milk consumption $(600 \mathrm{ml})$. Only a $418 \mathrm{~kJ} / \mathrm{d}$ increase in total energy intake was observed, implying a partial compensatory effect of milk on energy balance. Lau et al. ${ }^{(80)}$ also showed that women in the milk supplementation group ( $50 \mathrm{~g}$ milk powder/d), compared with the control group, gained body weight $(0.52 v .-0.26 \mathrm{~kg} ; P<0.01)$ and fat mass $(0.42 v \cdot-0.14 \mathrm{~kg} ; P<0 \cdot 01)$.
Conversely, seven trials ${ }^{(81-86)}$ showed no significant difference in body weight with milk supplementation or dairy treatment, four of which were specifically designed to assess bone health ${ }^{(81-84)}$ and one blood pressure ${ }^{(85)}$. Thus, although weight is a very robust outcome to measure, the studies should be interpreted with caution due to the possible lack of statistical power needed to detect significant differences in body weight.

Two studies ${ }^{(86,90)}$ that were primarily designed to examine the effect of dairy consumption on abdominal obesity failed to detect differences among the treatments. For example, Wennersberg et al. ${ }^{(90)}$ conducted a 6-month randomised parallel study in middle-aged overweight subjects with low habitual dairy intake ( $\leq$ two servings/d) and traits of the metabolic syndrome. There were no differences in BMI, body weight, waist circumference, sagittal abdominal diameter, body fat mass and proportion of body fat between the high dairy group (three to five servings/d) and the control group ( $\leq$ two servings/d). However, a post hoc analysis based on baseline Ca intake, which divided the participants into two groups, above or below the suggested threshold level of $700 \mathrm{mg} \mathrm{Ca}$, showed that subjects in the high dairy group, who had a baseline $\mathrm{Ca}$ intake less than $700 \mathrm{mg}$, had lower waist circumference $(P=0.003)$ and sagittal abdominal diameter $(P=0.034)$ compared with those in the control group at the end of the study. These findings further support the evidence from epidemiological studies suggesting the possible threshold effect of dietary $\mathrm{Ca}$ above which no 
additional benefit of increased dietary Ca intake with respect to body weight is evident.

Zemel et $a l^{(88)}$ conducted two intervention trials in African-American adults, with adiposity being the primary endpoint. The first 26-week randomised parallel trial was a weight-maintenance study and findings indicated that high dairy (three servings/d) compared with low dairy (< one serving/d) consumption decreased total body fat $(-2.158 v .0 .169 \mathrm{~kg} ; P<0.01)$ and trunk fat $(-1.026 v$. $-0.357 \mathrm{~kg} ; P<0.01)$ despite the fact that there was no significant change in body weight. Recently, Zemel et $a{ }^{(89)}$ conducted a 9-month study, of which the first 3 months were the weight-loss phase and months 4 to 9 the weight-maintenance phase when the high- or low-dairy intervention was introduced. During the weight maintenance, there were no differences in weight and body composition between the high dairy diet group ( $>$ three servings/d) and the low dairy group ( $<$ one serving/d). However, the high dairy diet group consumed $1038 \mathrm{~kJ} / \mathrm{d}$ $(P<0.05)$ more energy for the first half of maintenance and $837 \mathrm{~kJ} / \mathrm{d} \quad(P<0.05)$ more for the second half of maintenance relative to the low dairy group. Thus, there was no treatment effect on weight and body composition in spite of the higher energy intake in the high dairy group, where the additional energy would have been expected to contribute to weight gain.

One 12-month study ${ }^{(86)}$ included an intervention with Ca derived from both dairy and supplemental sources and no differences on body fatness and weight were observed. However, in a 6-month follow-up, Eagan et $a l .{ }^{(87)}$ demonstrated that the mean $\mathrm{Ca}$ intake, mainly from dairy products, during the period of 18 months predicted a negative change in fat mass $(P=0.04)$ when the model was adjusted for baseline BMI. According to their regression model, a Ca dose of $1200 \mathrm{mg} / \mathrm{d}$ predicted $0.631 \mathrm{~kg}$ fat mass loss while a dose of $500 \mathrm{mg} / \mathrm{d}$ predicted a fat mass gain of $1.26 \mathrm{~kg}$ over 18 months in normalweight young women.

Overall, data from the majority of the studies reviewed predict that body weight does not change due to increased consumption of dairy products. Thus, consumption of the recommended amount of dairy products could be incorporated into weight-maintenance diets without causing potential body weight loss. Although the inclusion of dairy products may have resulted in some undefined energy compensation, there was a trend for individuals in the dairy group to have an overall higher energy intake $^{(89,90)}$, which may override any potential beneficial effect attributable to their bioactive components.

\section{Evidence from intervention trials with energy restriction}

Five studies have explored the relationship between dairy product consumption and alterations in fat mass and body weight in an overweight and obese population during energy restriction ${ }^{(77,88,91-93)}$, with body composition being the primary endpoint of four studies ${ }^{(77,88,91,92)}$. In the second 24-week trial of Zemel et al. ${ }^{(88)}$, twentynine subjects on an energy-restricted regimen $(2092 \mathrm{~kJ} / \mathrm{d}$ below requirement) were assigned to a low-dairy $(<$ one serving/d) or high-dairy (three servings/d) diet. The data suggested that high-dairy diets promote greater weight and fat loss ( -11 and $-9 \mathrm{~kg}$, respectively; $P<0 \cdot 01)$ relative to low-dairy diets ( -9 and $-4 \mathrm{~kg}$, respectively; $P<0 \cdot 01$ ), and in particular promoted abdominal fat loss (2-fold greater loss in the high dairy $v$. the low dairy group; $P<0 \cdot 01)$. High dairy intake also seemed to protect against the loss of lean body mass during energy restriction ${ }^{(88)}$. Similar results were obtained when a diet rich in fat-free yoghurt (three $170 \mathrm{~g}$ servings/d) was provided to obese subjects during 3 months of energy restriction $(2092 \mathrm{~kJ} / \mathrm{d}$ deficit). There was an $81 \%(P<0 \cdot 001)$ greater reduction in trunk fat loss on the yoghurt diet $v$. the control diet

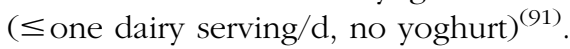

In contrast, three studies showed no evidence that a diet high in dairy products enhanced weight loss by overweight and obese individuals during periods of energy restriction $^{(77,92,93)}$. In a 12-month study with $2092 \mathrm{~kJ}$ energy deficit per d, fifty-four obese subjects were assigned to either a high-dairy diet $(1400 \mathrm{mg} \mathrm{Ca})$ or a low-dairy diet (about $700 \mathrm{mg} \mathrm{Ca})^{(92)}$. Body weight and fat loss did not statistically differ between the high-dairy diet and the lowdairy diet (weight loss: $9.6 \mathrm{~kg}$ and $10.8 \mathrm{~kg}(P=0.56)$ and fat loss: $9.0 \mathrm{~kg}$ and $10 \cdot 1 \mathrm{~kg}$, respectively). Similarly, Thompson et $a l .{ }^{(77)}$ failed to show a difference in body weight loss among three energy-restricted diets with $2092 \mathrm{~kJ}$ energy deficit per d. Participants lost $11.8 \mathrm{~kg}$ in the highdairy (four servings/d) diet, $10 \mathrm{~kg}$ in the moderate-dairy (two servings/d) diet and $10.6 \mathrm{~kg}$ in the high-fibre diet. Based on the review of these studies the apparent discrepancy may be attributed to the possible threshold effect of $600-800 \mathrm{mg}$ of dietary $\mathrm{Ca}$ above which weight loss is enhanced. A lack of effect of dairy products on weight loss as part of an energy-restricted diet was also reported by Bowen et $a l .{ }^{(93)}$, although bone turnover was the primary endpoint.

As far as $\mathrm{Ca}$ is concerned, three studies showed an inverse association between $\mathrm{Ca}$ intake and weight gain $^{(94-96)}$ and two studies ${ }^{(97,98)}$, which included an exercise intervention, concluded that diets rich in Ca may contribute to weight maintenance in either normal-weight or obese populations.

In summary, although there are inconsistent results among the studies regarding the promotion of weight loss with high-dairy diets, it is worth noting that inclusion of dairy products as part of an energy-restricted diet did not adversely affect weight loss. Future work needs to be conducted in order to compare effects of high dairy consumption with moderate and low dairy consumption on weight loss under energy restriction. Finally, further research is needed on the effect of the recommended dairy consumption on body composition during exercise interventions. 
Intervention trials: dairy products v. dietary and supplemental calcium

Two studies with body composition as their primary outcome have included energy-restricted intervention with both dietary $\mathrm{Ca}$ and supplemental $\mathrm{Ca}$ at comparable doses, thereby allowing a direct comparison ${ }^{(94,99)}$. As indicated in Fig. 4, Zemel et al. ${ }^{(94)}$ reported more effective weight and body fat loss in obese subjects who were under energy restriction $(2092 \mathrm{~kJ} / \mathrm{d}$ below requirement) and received $\mathrm{Ca}$ as dairy products compared with a $\mathrm{Ca}$ supplement. Those findings were further supported in a recent multi-centre 12 -week clinical trial conducted in 106 overweight and obese subjects under the same energy restriction $\left(2092 \mathrm{~kJ} / \mathrm{d}\right.$ below requirement ${ }^{(99)}$. The data suggested that a high-dairy diet promotes greater fat loss $(-4.43 \mathrm{~kg} ; P<0.0025)$ relative to high and low supplemental $\mathrm{Ca}(-2.23$ and $-2.69 \mathrm{~kg}$, respectively; $P<0.0025)$, in particular trunk fat loss $(P<0.05)$ and waist circumference $(P<0.025)$. However, it is noticeable that no differences were observed in weight loss in the second study ${ }^{(99)}$. The authors suggested the low adherence of subjects at one centre and consequently the loss of
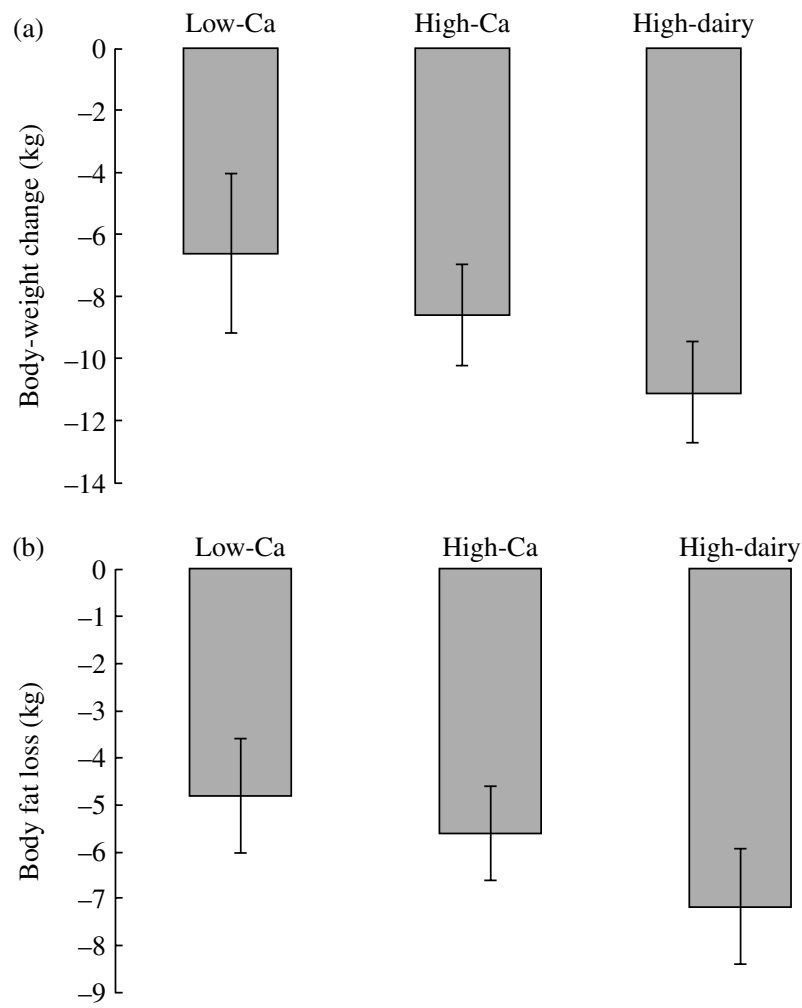

Fig. 4. The impact of dietary $\mathrm{Ca}$ consumption on adiposity. The effect of three different diets (low in supplemental Ca (Low-Ca; 430 (SE 94) mg Ca/d); high in supplemental $\mathrm{Ca}$ (High-Ca; 1256 (SE 134) $\mathrm{mg} \mathrm{Ca} / \mathrm{d}$ ); high in dairy $\mathrm{Ca}$ through high dairy product consumption (High-Dairy; 1137 (SE 164) mg $\mathrm{Ca} / \mathrm{d})$ ) on (a) 6 -month body weight loss $(P<0.01)$ and (b) 6 -month body fat change $(P<0.01)$ in obese individuals under an energy-restricted intervention. Values are means, with their standard errors represented by vertical bars (adapted from Zemel et al. ${ }^{(94)}$ ). statistical power as an explanation for the discrepancy. No differences in BMI and weight were also observed in a 12-month maintenance study ${ }^{(100)}$ in postmenopausal women who were randomly assigned to a high-dairy diet (1200 mg Ca plus $7.5 \mu \mathrm{g}$ vitamin $\mathrm{D}_{3}$ daily), a highsupplemental $\mathrm{Ca}$ diet (1200 mg Ca) and a control diet (usual diet). However, the high-dairy diet resulted in a greater loss of leg fat $(P=0.025)$ and a lower increase in the sum of skinfolds thickness $(P=0.042)$ compared with the high supplemental $\mathrm{Ca}$. The greater effect of dietary Ca $v$. supplemental Ca was also observed by Ochner \& Lowe ${ }^{(95)}$, who showed an inverse effect of dietary $\mathrm{Ca}$ and no effect of supplemental $\mathrm{Ca}$ consumption on weight regain 12 months after control of energy intake for 6 months $(P=0.048$ for FFQ and $P=0.025$ for food records).

\section{Summary of the evidence based on epidemiological and intervention studies}

Although inconsistencies between studies certainly exist, the overall assessment of the epidemiological evidence is suggestive of a modest negative association between dairy consumption and body weight. The overall linear regression analysis, based on the eighteen trials that examined dietary $\mathrm{Ca}$ (with the majority of dietary $\mathrm{Ca}$ derived from dairy products), indicates that an increase in $\mathrm{Ca}$ intake from 400 to $1200 \mathrm{mg} / \mathrm{d}$ would be associated with a decrease in BMI from 25.6 to $24.7 \mathrm{~kg} / \mathrm{m}^{2}$. Evidence derived from intervention studies without energy restriction does not predict any effect of dairy products on either weight loss or weight gain. During energy restriction, although the results are still inconsistent, there are indications of a possible beneficial effect of dairy products in weightloss treatments whilst maintaining lean tissue in an overweight population. There is a possible threshold effect of $600-800 \mathrm{mg}$ of dietary Ca above which fat loss is augmented. A stronger effect of equivalent $\mathrm{Ca}$ intakes as dairy $v$. the supplemental form is indicative that dairy components other than $\mathrm{Ca}$ may in part mediate the beneficial impact on body weight and composition.

\section{Mechanism underlying the impact of dairy constituents on body-weight regulation}

The potential mechanisms underlying the impact of dairy constituents on the regulation of energy metabolism, body weight or body fat have not been clearly elucidated. The most highly cited plausible mechanisms refer to dietary $\mathrm{Ca}$ and its effects on intracellular $\mathrm{Ca}$, and subsequent impact on adipocyte lipid metabolism and fatty acid absorption from the gastrointestinal tract ${ }^{(101)}$. However, a number of dairy constituents such as protein, fat and their metabolites have also been widely reported to play a potential role in weight regulation (Fig. 5). 


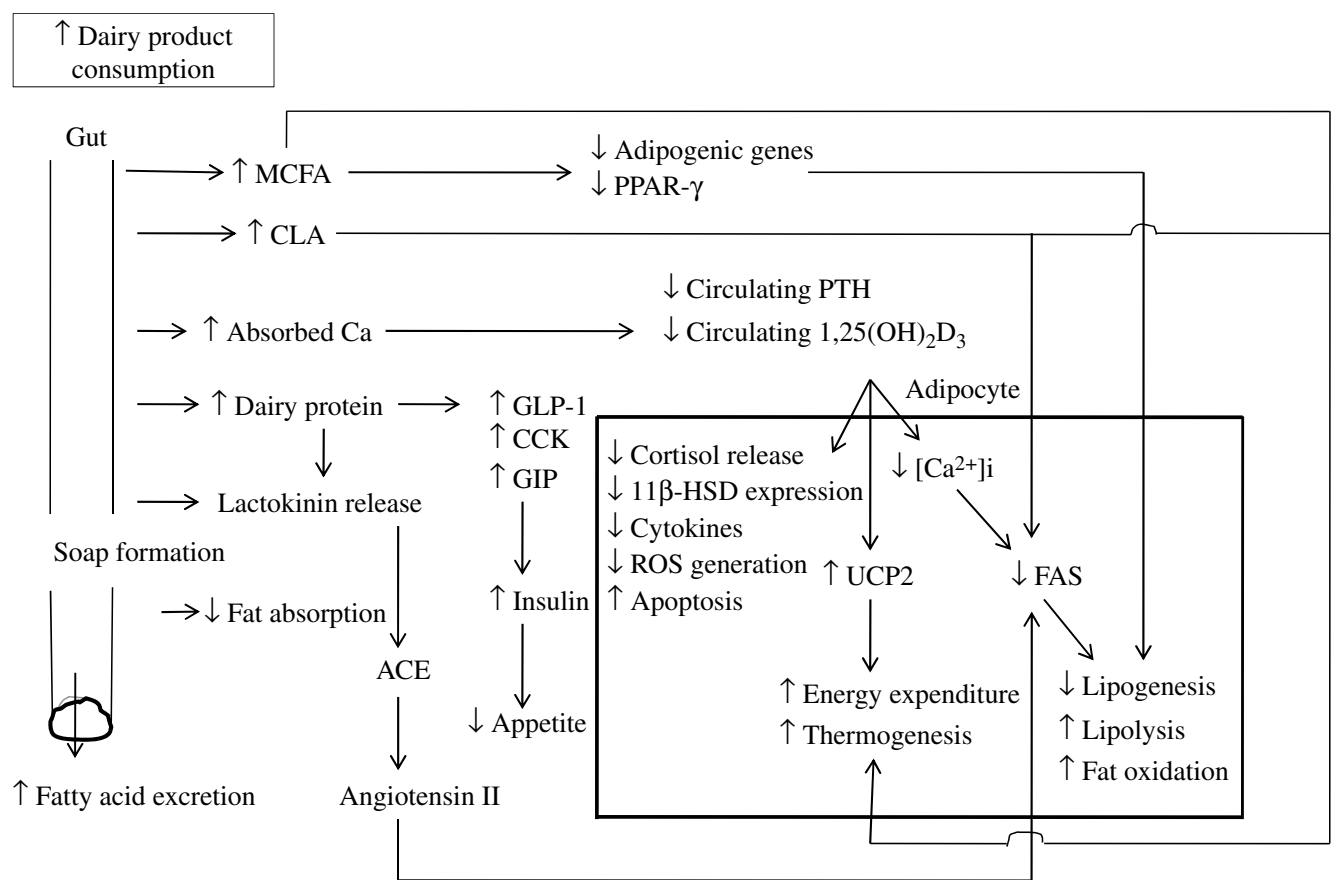

Fig. 5. Proposed mechanisms underlying the effect of dairy intake on body adiposity (adapted from Scholz-Ahrens \& Schrezenmeir ${ }^{(214)}$ ). $\uparrow$, Increase; MCFA, medium chain fatty acids; $\downarrow$, decrease; CLA, conjugated linoleic acid; PTH; parathyroid hormone; $1,25(\mathrm{OH})_{2} \mathrm{D}_{3}$, calcitriol; GLP-1, glucagon-like-peptide-1; CCK,

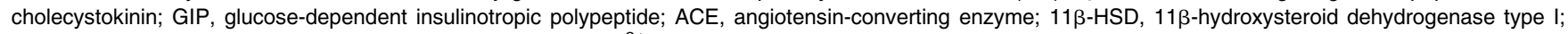
ROS, reactive oxygen species; UCP2, uncoupling protein-2; $\left[\mathrm{Ca}^{2+}\right]$ i, intracellular $\mathrm{Ca}$; FAS, fatty acid synthase.

\section{Mechanisms underlying the impact of calcium on body composition}

Effects of calcium on adipocyte lipid metabolism. Zemel et $a .^{(36,102)}$ were the first to explore the association between low $\mathrm{Ca}$ intake and fat accumulation. The authors suggested that intracellular $\mathrm{Ca}^{2+}$ promotes energy storage due to the stimulation of de novo lipogenesis through the regulation of fatty acid synthase and inhibition of lipolysis through the activation of phosphodiesterase $3 \mathrm{~B}^{(103)}$. The concentration of intracellular $\mathrm{Ca}^{2+}$ in human adipocytes is increased by the stimulation of Ca-regulating hormones such as parathyroid hormone and 1,25 dihydroxyvitamin $\mathrm{D}_{3}\left(1,25(\mathrm{OH})_{2} \mathrm{D}_{3}\right)^{(104)}$. Low dietary $\mathrm{Ca}$ intake increases blood concentration of calcitropic hormones (parathyroid hormone and $1,25(\mathrm{OH})_{2} \mathrm{D}_{3}$ ) and intracellular $\mathrm{Ca}$ influx, thereby decreasing lipolysis and increasing lipogenesis, leading to increased TAG storage.

In addition to these functions, decreased $1,25(\mathrm{OH})_{2} \mathrm{D}_{3}$ may increase the expression of uncoupling protein-2 (UCP2) via the nuclear vitamin D receptor in white adipose tissue and hence may contribute to improved thermogenesis (Fig. 5) ${ }^{(105,106)}$. However, there are animal ${ }^{(107)}$ and human ${ }^{(108,109)}$ studies showing no alterations of UCP2 and consequently no differences in diet-induced thermogenesis. Thus, the role of UCP2 is still not clear, and other unknown mechanisms may lead to this thermogenic effect.

The regulation of both UCP2 and intracellular $\mathrm{Ca}^{2+}$ by calcitriol hormone appears to modulate apoptotic cell death via a dose-dependent mechanism ${ }^{(110,111)}$. Furthermore, some additional mechanisms have been proposed by Zemel \& Sun ${ }^{(110)}$ who suggested that decreased $1,25(\mathrm{OH})_{2} \mathrm{D}_{3}$ (which is associated with higher $\mathrm{Ca}$ intakes) down-regulates $11 \beta$-hydroxysteroid dehydrogenase type I expression and decreases the concentration of glucocorticoid which consequently decreases the size of the adipose fat deposit ${ }^{(112)}$ (Fig. 5). In addition, the potential impact of $1,25(\mathrm{OH})_{2} \mathrm{D}_{3}$ on adiposity includes effects on adipocyte differentiation and proliferation via the regulation of reactive oxygen species and inflammatory cytokines (Fig. 5) ${ }^{(113)}$. Finally, a low level of calcitriol has been shown to decrease the expression of pro-inflammatory factors (TNF- $\alpha$ and IL-6) and increase the expression of anti-inflammatory factors (IL-15 and adiponectin) in visceral fat ${ }^{(114)}$.

Although the adipocyte fat metabolism hypothesis has gained support from both cell-culture and rodent studies as detailed above, recent human studies failed to show an effect of dairy $\mathrm{Ca}$ on adipocyte and whole-body lipid metabolism $^{(108,115,116)}$. Bortolotti et al. ${ }^{(116)}$ have highlighted potential flaws of the above hypothesis, including an observation of a relationship between obesity with low vitamin $\mathrm{D}$ and $1,25(\mathrm{OH})_{2} \mathrm{D}_{3}$ concentrations $^{(117,118)}$ and highlight that de novo lipogenesis is likely to make a minor contribution to fat accumulation in humans on a typical mixed Western diet. Since there is currently a paucity of data from human trials, further research is required to explore the effect of $\mathrm{Ca}$ on human adipocyte fat metabolism. 
Evidence of calcium effects on fat oxidation. Melanson et $a l .{ }^{(119)}$ were the first to examine any association between $\mathrm{Ca}$ intake and whole-body fat oxidation. Their results suggest a positive correlation between total acute $\mathrm{Ca}$ intake and $24 \mathrm{~h}(r 0.38 ; P=0.03)$ and sleeping fat oxidation ( $r 0.36 ; P=0.04)$. However, a limitation of this study is the fact that no correction for differences in protein intake was made, with protein previously shown to have an effect on weight regulation and thermogenesis ${ }^{(120,121)}$. Therefore, conclusions cannot be drawn from this trial regarding the independence of the impact of $\mathrm{Ca}$ intake on fat oxidation. A subsequent study by the same group ${ }^{(122)}$ showed that a high dairy $\mathrm{Ca}$ intake increased $24 \mathrm{~h}$ whole-body fat oxidation by $28 \%(P=0.02)$ under a regimen with a combination of energy restriction $(2510 \mathrm{~kJ} / \mathrm{d}$ below requirement) and exercise, with the latter being the main stimulus of the fat oxidation. Several additional studies have examined the effect of $\mathrm{Ca}$ or dairy consumption on fat oxidation and energy expenditure, but the results are controversial (Table 4) ${ }^{(89,108,109,115,116,123-125)}$. Furthermore, the mechanism by which dietary $\mathrm{Ca}$ may mediate fat oxidation requires further investigation, although an increase in UCP2 associated with increased $\mathrm{Ca}$ intake may be involved $^{(105)}$.
Evidence of calcium effects on fatty acid absorption and postprandial fat metabolism. As previously mentioned, an alternative mechanism that has been suggested to be responsible for the effect of $\mathrm{Ca}$ and dairy product consumption on body adiposity is reduced fat absorption from the gastrointestinal tract (Fig. 5). This mechanism is attributed to the capability of $\mathrm{Ca}^{(101)}$ to increase faecal excretion of fat via the formation of insoluble fatty acid soaps in the gut or by binding of bile acids, which weakens the formation of micelles ${ }^{(124,126-128)}$. It is generally accepted that high-Ca diets increase fat excretion (Table 5) ${ }^{(126-129)}$. In a recent meta-analysis conducted by Christensen et al. ${ }^{(130)}$ which examined the impact of $\mathrm{Ca}$ intervention, both as dairy and supplemental $\mathrm{Ca}$, a 0.99 increase of standardised mean difference in faecal fat excretion (95\% CI 0.63, 1.34; $P<0.0001$ ) was observed which corresponds to about $2 \mathrm{~g} / \mathrm{d}$ with a moderate heterogeneity among the studies $\left(I^{2}=49 \cdot 5 \%\right)$. However, when only dairy trials were analysed, there was no heterogeneity and results indicated that dairy Ca consumption of $1241 \mathrm{mg}$ increased faecal fat excretion by $5 \cdot 2 \mathrm{~g} / \mathrm{d}(95 \%$ CI 1.6, 8.8) compared with low dairy Ca consumers $(<700 \mathrm{mg} / \mathrm{d})$. Based on the authors' estimates, this fat excretion would translate into $1.9 \mathrm{~kg}$ body fat or $2.2 \mathrm{~kg}$

Table 4. Studies evaluating the effect of calcium on fat oxidation

\begin{tabular}{|c|c|c|}
\hline Authors & Details & Results and conclusion \\
\hline Zemel et al. (2008) ${ }^{(89)}$ & $\begin{array}{l}\text { A 9-month randomised trial; } 338 \text { subjects (obese) } \\
\text { Diets: (a) LD (<one serving/d); (b) HD (>three servings/d) }\end{array}$ & $\begin{array}{l}\text { During the weight-maintenance phase }(3-9 \text { months }) \\
\text { the HD group had a greater RMR }(P<0.08) \text { and } \\
\text { increase in fat oxidation }(P<0.01)\end{array}$ \\
\hline Cummings et al. $(2006)^{(109)}$ & $\begin{array}{l}\text { A within-subject randomised trial; six men and two women } \\
\text { (overweight) } \\
\text { Diets: (a) LDCa (176 mg); (b) HNDCa (calcium citrate) } \\
\quad(575 \mathrm{mg}) ; \text { (c) HDCa (532 mg) }\end{array}$ & $\begin{array}{l}\text { HDCa and HNDCa subjects increased postprandial } \\
\text { fat oxidation rate compared with LDCa subjects } \\
\text { (mean change in } 6 \mathrm{~h} \text { fat oxidation from the fasting } \\
\text { state was } 3 \cdot 3 \text { (SEM } 2 \cdot 5 \text { ), } 2 \cdot 9 \text { (SEM } 2 \cdot 3 \text { ) and }-6.5 \\
\text { (SEM } 2 \cdot 2 \text { ) } \mathrm{g} / 6 \mathrm{~h} \text {, respectively) }\end{array}$ \\
\hline Boon et al. $(2005)^{(115)}$ & $\begin{array}{l}\text { A randomised cross-over trial; twelve men, } 3 \times 1 \text { week, } \\
24 \mathrm{~h} \text { fat oxidation } \\
\text { Diets: (a) HCa/HD }(1259 \mathrm{mg} / \mathrm{d}) \text {; (b) HCa/LD }(1259 \mathrm{mg} / \mathrm{d}) \text {; } \\
\text { (c) } \mathrm{LCa} / \mathrm{LD}(349 \mathrm{mg} / \mathrm{d})\end{array}$ & $\begin{array}{l}\text { Fat oxidation of } 108 \text { (SE 7) } g / 24 \mathrm{~h} \text { for } \mathrm{HCa} / \mathrm{HD} 105 \\
\text { (SE 9) } \mathrm{g} / 24 \mathrm{~h} \text { for } \mathrm{HCa} / \mathrm{LD} \text { and } 100(\mathrm{SE} 6) \mathrm{g} / 24 \mathrm{~h} \text { for } \\
\mathrm{LCa} / \mathrm{LD} \text {. No statistically significant difference. } \\
\text { No influence on expression of genes that are } \\
\text { closely related to fat metabolism and are regulated } \\
\text { by serum } 1,25(\mathrm{OH})_{2} \mathrm{D}_{3}\end{array}$ \\
\hline Bortolotti et al. $(2008)^{(116)}$ & $\begin{array}{l}\text { A randomised cross-over trial; seven women and three men, } \\
2 \times 5 \text { weeks, } 7 \mathrm{~h} \text { fat oxidation } \\
\text { Diets: (a) dairy } \mathrm{Ca}(800 \mathrm{mg} / \mathrm{d}) \text { with maltodextrin; } \\
\text { (b) maltodextrin }\end{array}$ & $\begin{array}{l}\text { Ca supplementation had no effect on plasma PTH } \\
\text { concentration, on resting energy expenditure }(250 \cdot 6 \\
\text { (SE } 12 \cdot 6) \text { or } 249.4(\mathrm{SE} 13 \cdot 3) \mathrm{kJ} / \mathrm{h} \text { ) and on fat } \\
\text { oxidation ( } 58.4(\mathrm{SE} 2 \cdot 2) \text { or } 53 \cdot 8(\mathrm{SE} 2 \cdot 2) \mathrm{mg} / \mathrm{min}) \\
\text { compared with the placebo diet }\end{array}$ \\
\hline Gunther et al. $(2005)^{(123)}$ & $\begin{array}{l}\text { A parallel randomised trial; nineteen women, 1-year } \\
\text { intervention } \\
\text { Diets: (a) LCa, dietary }(<800 \mathrm{mg} / \mathrm{d}) \text {; (b) HCa dietary } \\
\quad(1000-1400 \mathrm{mg} / \mathrm{d})\end{array}$ & $\begin{array}{l}\text { There was increased whole-body fat oxidation and } \\
\text { decreased PTH concentration with a diet rich in } \\
\text { dietary Ca, mainly from dairy food }(P<0.05)\end{array}$ \\
\hline Jacobsen et al. (2005) $)^{(124)}$ & $\begin{array}{l}\text { A randomised cross-over trial; eight women and two men, } \\
3 \times 1 \text { week, } 24 \mathrm{~h} \text { fat oxidation } \\
\text { Diets: (a) LCa/NP ( } 500 \mathrm{mg} \mathrm{Ca}, 15 \mathrm{E} \% \text { protein); (b) } \mathrm{HCa} / \mathrm{NP} \\
(1800 \mathrm{mg} \mathrm{Ca}, 15 \mathrm{E} \% \text { protein); (c) } \mathrm{HCa} / \mathrm{HP}(1800 \mathrm{mg} \mathrm{Ca} \text {, } \\
23 \mathrm{E} \% \text { protein) }\end{array}$ & $\begin{array}{l}\text { No effect of Ca consumption on fat oxidation, } 24 \mathrm{~h} \text { EE } \\
\text { but } 2.5 \text {-fold increase in faecal fat excretion during } \\
\text { the } \mathrm{HCa} / \mathrm{NP}, \mathrm{LCa} / \mathrm{NP} \text { and } \mathrm{HCa} / \mathrm{HP} \text { diets }(14.2,6.0 \\
\text { and } 5.9 \mathrm{~g} / \mathrm{d} \text {, respectively; } P<0.05)\end{array}$ \\
\hline Teegarden et al. $(2008)^{(125)}$ & $\begin{array}{l}\text { A parallel randomised trial; twenty-four women, } 12 \text { weeks } \\
\text { Diets (all under } 2092 \mathrm{~kJ} / \mathrm{d} \text { energy deficit): (a) placebo } \\
\text { (<800 mg Ca/d); (b) } 900 \mathrm{mg} \mathrm{CaCO} / \mathrm{d} \text {; (c) three } \\
\text { servings of dairy products per d to achieve } 900 \mathrm{mg} \mathrm{Ca} / \mathrm{d}\end{array}$ & $\begin{array}{l}\text { Only the Ca-supplemented group had increased } \\
\text { fat oxidation }(1.5(\mathrm{SD} 0.6) \mathrm{g} / \mathrm{h} ; P=0.02) \text { during the } \\
\text { 12-week intervention. No effects on total energy } \\
\text { expenditure were observed by all groups }\end{array}$ \\
\hline
\end{tabular}

LD, low dairy; HD, high dairy; LDCa, low in dairy Ca; HNDCa, high in non-dairy Ca; HDCa, high in dairy Ca; HCa, high Ca; LCa, low Ca; 1,25(OH) $2 \mathrm{D}_{3}, 1,25$ dihydroxyvitamin $\mathrm{D}_{3}$; PTH, parathyroid hormone; NP, normal protein; HP, high protein; E\%, percentage of energy; EE, energy expenditure. 
body-weight loss over a year. However, due to the small number of studies and the small number of participants on each study, a dose-response relationship could not be established. The importance of faecal fat excretion on body-weight regulation remains to be confirmed by long-term studies with more robust designs.

Furthermore, Jacobsen et al..$^{(124)}$ and Boon et al. ${ }^{(108)}$ (Table 5) implied that the impact of $\mathrm{Ca}$ on fat absorption may be protein dependent. The authors suggested that $\mathrm{Ca}$ is bound by dietary protein, especially caseins, and that $\mathrm{Ca}$-protein complexation may reduce the amount of $\mathrm{Ca}$ available for the formation of fatty acid soaps ${ }^{(124)}$, and therefore may in part negate the impact of $\mathrm{Ca}$ on fat absorption.

Lorenzen et al. ${ }^{(131)}$ recently investigated the effect of high Ca consumption from dairy products or supplemental $\mathrm{Ca}$ on postprandial fat metabolism. Four isoenergetic meals were used containing high $(172 \mathrm{mg} / 1000 \mathrm{~kJ})$, medium $(84 \mathrm{mg} / 1000 \mathrm{~kJ})$ or low $(15 \mathrm{mg} / 1000 \mathrm{~kJ})$ amounts of $\mathrm{Ca}$ from dairy products and a calcium carbonate supplement $(183 \mathrm{mg} / 1000 \mathrm{~kJ})$. According to their findings, high Ca intake from dairy products decreased postprandial lipaemia compared with the low $\mathrm{Ca}$ intake (adjusted area under the curve about 19\% lower) and compared with the supplementary $\mathrm{Ca}$ (about $17 \%$ lower). The differences between dairy $v$. supplemental $\mathrm{Ca}$ could be explained by the differences in the chemical form of $\mathrm{Ca}$ (calcium phosphate in dairy products being more soluble than the calcium carbonate in the supplement ${ }^{(132)}$ ), a difference in $\mathrm{pH}$ and in other bioactive components in dairy products, which may have had an impact on the postprandial lipaemic response.

\section{Mechanisms and evidence of conjugated linoleic acid effects on body composition}

As already mentioned, data suggest that $\mathrm{Ca}$ from dairy products has greater effects on body-weight regulation than supplemental $\mathrm{Ca}^{(94,133)}$, which would lead to the hypothesis that dairy foods can influence body adiposity by Ca-independent mechanisms. Conjugated linoleic acid (CLA) is a potential group of bioactive components which may have an impact, with dairy products, beef and lamb representing the almost exclusive dietary sources ${ }^{(134)}$. Although the impact of CLA on body fat mass and topography has been repeatedly demonstrated in rodent models, the results of human trials are equivocal $^{(135)}$. A recent review by Plourde et al. ${ }^{(136)}$ indicated that the differences in results may arise from the different experimental design, age, sex, energy intake and CLA metabolism of the participants, and the dose and chemical form of the CLA isomer administered. The predominant isomer of CLA in natural foods is the cis-9, trans-11-CLA 'rumenic acid' which accounts for more than $90 \%$ of the total CLA intake. However, it is strongly suggested that other isomers, such as trans-10, cis-12-CLA, 
may influence body-weight and fat changes ${ }^{(137)}$. Thus, it is questionable whether physiological doses of CLA, consumed as dairy products, can have any meaningful impact on body-weight regulation in humans. Furthermore, potential underlying mechanisms are poorly understood, with proposed mechanisms suggesting that CLA can inhibit fatty acid synthase and stearoyl-CoA desaturase- $1^{(137)}$, enhance fat oxidation and thermogenesis and reduce lipogenesis and preadipocyte differentiation and proliferation ${ }^{(138)}$.

\section{Effects of medium-chain fatty acids on body composition}

Dairy products are a source of medium-chain TAG of which 6:0 (capronic acid), 8:0 (caprylic acid) and 10:0 (capric acid) collectively constitute $4-12 \%$ of all fatty acids in bovine milk, with 12:0 (lauric acid) comprising $2-5 \%{ }^{(139)}$. Animal trials have shown decreased lipogenesis and TAG synthesis with increased medium-chain fatty acid intake ${ }^{(140)}$. Likewise, clinical trials in human subjects have revealed that diets rich in medium-chain fatty acids are associated with a reduction in body fat in human subjects $^{(139,141-144)}$. Tsuji et al. ${ }^{(143)}$ assigned volunteers to diets providing $9213 \mathrm{~kJ} / \mathrm{d}$ and $60 \mathrm{~g}$ total $\mathrm{fat} / \mathrm{d}, 10 \mathrm{~g}$ of which were either medium-chain TAG or long-chain TAG, for 12 weeks. A reduction in body weight (medium-chain TAG: $-6.12 \mathrm{~kg}$; long-chain TAG: $-4.78 \mathrm{~kg}$ ) and body fat (medium-chain TAG: $-4.57 \mathrm{~kg}$; long-chain TAG: $-3.61 \mathrm{~kg}$ ) was observed in both groups, with greater effects in the medium-chain TAG group, and particularly among subjects with $\mathrm{BMI} \geq 23 \mathrm{~kg} / \mathrm{m}^{2}$. These findings were in general agreement with another study ${ }^{(144)}$ that provided $5 \mathrm{~g}$ of medium-chain TAG, which is lower than the typical level of medium-chain TAG intake $(15 \mathrm{~g})^{(145)}$, and highlight the potential role of medium-chain TAG in the putative impact of dairy products on body composition.

Medium-chain fatty acids are transported directly via the portal vein to the liver, increase postprandial thermogenesis and are rapidly oxidised to ketones via $\beta$-oxidation rather than incorporated into adipose tissue $\mathrm{TAG}^{(146)}$. In addition, medium-chain fatty acids may contribute to a reduction in fat mass through down-regulation of adipogenic genes and PPAR- $\gamma^{(139)}$, an essential transcription factor of adipogenesis whose activation is stimulated by the binding of lipophilic ligands ${ }^{(147)}$.

\section{Effects of proteins on body composition}

Dairy products contain a number of bioactive peptides that may act synergistically or independently with Ca to regulate body adiposity ${ }^{(148)}$. The milk proteins casein ${ }^{(149)}$ and, particularly, whey are rich sources of potentially bioactive peptides (casokinins and lactokinins, respectively) that have been shown to inhibit angiotensin-converting enzyme, and consequently inhibiting the production of the angiotensin II hormone ${ }^{(148)}$. In addition to the role of angiotensin II in the regulation of vascular smooth muscle function, vascular tone and blood pressure, it has been shown to up-regulate fatty acid synthase expression, resulting in adipocyte lipogenesis (Fig. 5) ${ }^{(150)}$.

Milk proteins have also been shown to stimulate insulin secretion, and whey proteins proved to be more insulinotropic compared with caseins or other animal and plant proteins $^{(151)}$. This insulin secretion may directly affect food intake regulation by suppressing appetite and, as a consequence, indirectly affect body weight. Furthermore, dairy proteins contain a high proportion (about 21-26\%) ${ }^{(152)}$ of the three branched-chain amino acids leucine, isoleucine and valine with their unique role in stimulating protein synthesis and in sparing lean body mass during weight-loss regimens ${ }^{(153)}$.

\section{Mechanism underlying the impact of dairy constituents on appetite regulation}

There is accumulating evidence to suggest that specific dairy product components affect body weight through their effects on food intake regulation and satiety ${ }^{(154)}$.

\section{Food intake regulation}

The peripheral and central nervous systems are involved in both short-term and long-term regulation of food intake by mechanisms and pathways that are distinct, yet act synergistically to either stimulate or suppress food intake ${ }^{(155)}$.

Long-term regulation of food intake. The arcuate nucleus in the hypothalamic region is where the major interactions of the appetite-regulator hormones occur ${ }^{(156)}$. The hypothalamus plays a critical role in the long-term regulation of food intake and is activated in response to hormones that enter or are produced in the central nervous system ${ }^{(155,157)}$ The adipocyte-derived leptin and pancreatic insulin are the two major anorexigenic (appetite-suppressing) hormones involved in the long-term regulation of appetite ${ }^{(158)}$ and resistance in the brain to their actions causes stimulation of appetite ${ }^{(159,160)}$.

Ghrelin is the only known orexigenic (appetite-stimulating) hormone, which is produced primarily in the stomach, and it has recently been suggested to contribute not only to the short-term but also to long-term regulation of food intake $^{(161)}$. Leptin and insulin, as regulators of feed intake, increase the secretion of anorexigenic neuropeptides and decrease the secretion of orexigenic neuropeptides (Table 6), while ghrelin has the opposite effects ${ }^{(155)}$.

Short-term regulation of food intake. Satiation refers to the physiological factors that promote meal termination while satiety refers to the events that influence the time interval between meals. Hence, satiation and satiety regulate meal size and frequency, respectively ${ }^{(162)}$. Both are included in the short-term regulation of food intake, 
Table 6. Major hormones and neuropeptides that regulate food intake

\begin{tabular}{lll}
\hline Name & \multicolumn{1}{c}{ Origin } & $\begin{array}{c}\text { Effect on } \\
\text { food intake }\end{array}$ \\
\hline $\begin{array}{ll}\text { Long-term } \\
\text { Leptin }\end{array}$ & Adipose tissue & $\downarrow$ \\
Insulin & Pancreas & $\downarrow$ \\
Pro-opiomelanocortin & Hypothalamus & $\downarrow$ \\
$\alpha$-Melanocyte-stimulating hormone & Hypothalamus & $\downarrow$ \\
Corticotrophin-releasing hormone & Hypothalamus & $\downarrow$ \\
Thyrotropin-releasing hormone & Hypothalamus & $\downarrow$ \\
Ghrelin & Gl tract & $\uparrow$ \\
Neuropeptide Y & Hypothalamus & $\uparrow$ \\
Agouti-related protein & Hypothalamus & $\uparrow$ \\
Melanin-concentrating hormone & Hypothalamus & $\uparrow$ \\
Orexins & Hypothalamus & $\uparrow$ \\
Short-term & Gl tract & \\
Cholecystokinin & Gl tract & $\downarrow$ \\
Glucagon-like peptide-1 & Gl tract & $\downarrow$ \\
Peptide tyrosine tyrosine & Gl tract & $\downarrow$ \\
Oxyntomodulin & Stomach & $\downarrow$ \\
Bombesin & Dietary BAP & $\downarrow$ \\
Opioids & Adipose tissue & $\downarrow$ \\
Leptin & Pancreas & $\downarrow$ \\
Insulin & Gl tract & $\uparrow$ \\
Ghrelin &
\end{tabular}

$\downarrow$, Suppression; Gl, gastrointestinal; $\uparrow$, stimulation; BAP, bioactive peptides.

which involves peptides primarily found in the enteric nervous system and entero-endocrine cells of the gastrointestinal tract ${ }^{(163)}$. The gastrointestinal tract, which includes the stomach, endocrine pancreas, proximal small intestine, distal small intestine and colon ${ }^{(156)}$, initiates a variety of satiety signals that act mainly through the brainstem. The brainstem is the principal centre that receives and transmits neural (by vagal afferents) and hormonal (by gut peptides) signals from the gastrointestinal tract ${ }^{(157)}$. A number of gut peptide hormones that have effects on appetite and food intake have been indentified to date, including cholecystokinin (CCK), glucagon-like peptide-1 (GLP-1), peptide tyrosine tyrosine, oxyntomodulin ${ }^{(164)}$ bombesin and ghrelin (Table 6) ${ }^{(165)}$. The secretion and regulation of these gut hormones depend not only on the macronutrient composition of the diet but also on neuroendocrine factors ${ }^{(164)}$. Additionally, dietary bioactive peptides such as the opioid-like peptides (casomorphins and caseinomacropeptide) are detectable in blood following the digestion of casein and may also induce satiety. The bioactive peptides can act as satiety hormones themselves or can stimulate the gut hormones ${ }^{(166)}$. Insulin and leptin, although major long-term regulators of food intake, are also involved in short-term regulation by increasing the actions of peripheral satiation signals such as $\mathrm{CCK}^{(167,168)}$

In summary, appetite is influenced by a number of peptides and hormones derived from the adipose tissue, gastrointestinal tract and pancreas, which, through their actions on the hypothalamus, the brainstem and the nervous system, regulate long- and short-term food intake (Table 6).

\section{Dairy components and appetite regulation}

Effects of dairy proteins. Among the dairy components, the proteins have the greatest putative role in appetite control. The satiating attributes of dietary protein relative to carbohydrate and fat are well recognised, and diets high in protein content are more satiating than low-protein $\operatorname{diets}^{(120,169)}$. It has been proposed that the effect of protein in short-term food regulation is associated with the increased plasma concentrations of gut peptide hormones known to reduce gastric emptying, gut motility and appetite ${ }^{(170)}$. This effect is related to the source of protein ${ }^{(171)}$. The major protein groups present in bovine milk are whey proteins (for example, $\beta$-lactoglobulin and $\alpha$-lactalbumin) and caseins $\left(\alpha_{\mathrm{s} 1}\right.$-casein, $\alpha_{\mathrm{s} 2}$-casein, $\beta$-casein and $\kappa$-casein) which constitute approximately 20 and $80 \%$, respectively ${ }^{(172)}$. Whey proteins emerge as potential regulators of body weight and have been shown to have more potent effects on appetite and anorexic gut peptide concentrations than caseins $^{(173-175)}$. In contrast, Bowen et al. ${ }^{(176)}$ showed no differences between casein and whey proteins or among whey, soya protein and gluten on ad libitum food intake ${ }^{(177)}$. Nevertheless, ghrelin and insulin concentrations were significantly decreased whilst CCK and GLP-1 was increased after whey, soya and gluten consumption compared with glucose. Additionally, a reduction in ad libitum energy intake of approximately $10 \%(P<0.05)$ was measured $3 \mathrm{~h}$ after casein and whey protein consumption compared with glucose consumption ${ }^{(176,177)}$. However, a recent study by the same group revealed no impact of whey protein consumption on ad libitum intake $4 \mathrm{~h}$ after consumption compared with fructose and glucose beverages ${ }^{(178)}$. Diepvens et al. ${ }^{(179)}$ showed that, although milk protein had greater stimulatory effects on the proposed satiety hormones CCK and GLP-1, this was not correlated with self-reported satiety, implying that satiety biomarkers do not always guarantee the highest satiety. The fact that there is no mathematical association between anorexigenic hormone responses and satiety is further supported by Veldhorst et al. ${ }^{(169)}$. These discrepancies among the studies of food intake may be due to different methodologies, possible interactions among the different macronutrients, and due to the different time periods for which food intake was assessed. Moreover, none of the above studies except Anderson et al. ${ }^{(174)}$ used a no-energy control preload; thus the effect of the preload consumption on food intake suppression was not assessed.

Although both whey and casein proteins induce satiety, they lead to different effects on appetite regulation ${ }^{(171)}$. Based on their contribution to protein synthesis and their effects on plasma amino acid concentrations, whey proteins have been classified as fast proteins and caseins have been classified as slow proteins ${ }^{(180)}$. This classification represents the greater effect of whey on suppressing food intake at $90 \mathrm{~min}$ and casein at $150 \mathrm{~min}$ after meal consumption ${ }^{(181)}$. Both caseinomacropeptide and 
casomorphins, released upon the digestion of caseins, interact with opioid receptors and slow gastrointestinal motility contributing to the longer transit time ${ }^{(154)}$. Moreover, whey (a by-product of cheese production) ${ }^{(181)}$ rich in glycomacropeptide (GMP) has been found to have a greater effect on pancreatic and gastrointestinal hormone secretion than whey alone or whey without $\operatorname{GMP}^{(169,182,183)}$. Veldhosrt et al. ${ }^{(183)}$ recently showed that subjects who consumed a breakfast containing whey without GMP had a higher energy intake at lunch compared with subjects who ate a breakfast containing whey with naturally present $21 \%$ GMP $(3208 \mathrm{~kJ}$ and $2877 \mathrm{~kJ}$, respectively; $P<0.05$ ).

Effects of dairy carbohydrates. Carbohydrate intake also contributes to satiety and appetite regulation ${ }^{(184)}$. Short-term studies $(\leq 1 \mathrm{~d})$ have demonstrated that lowglycaemic index foods increase satiety and reduce energy intake by affecting the blood glucose concentration and therefore the insulin response (glucostatic theory), and by stimulating gut peptides such as CCK, GLP-1 and peptide tyrosine tyrosine (PYY) ${ }^{(185,186)}$. However, the association between postprandial glycaemic response and satiety is still an issue of debate $(187,188)$

Lactose, which is the only carbohydrate found in milk $^{(189)}$, is traditionally classed as a low-glycaemic index carbohydrate (glycaemic index of lactose 46) and may contribute to the satiating impact of milk and dairy products. Bowen et $a l^{(176)}$ compared the acute postprandial effect of whey and casein proteins, lactose and glucose on energy intake and appetite hormones (ghrelin, GLP-1, CCK and insulin) in overweight men. The energy intake was $10 \%$ lower and acute appetite was also lower after the lactose and protein preloads comparing with glucose and this was consistent with differences in plasma ghrelin concentration.

Effects of dairy fats. Although fat is the least satiating macronutrient ${ }^{(190)}$, it may be one of the milk and dairy product components that contributes to satiety ${ }^{(191)}$. Similar to proteins and carbohydrates, the type and the structure of fatty acids, their chain length ${ }^{(192)}$, and their degree of saturation are characteristics that have an impact on appetite $^{(193)}$. A recent review revealed that fat increases gastrointestinal transit time, stimulates the secretion of many gastrointestinal hormones (CCK, GLP-1, peptide tyrosine tyrosine) and suppresses appetite and energy intake as a result of fat digestion into NEFA ${ }^{(194)}$. Haug et al. ${ }^{(195)}$ suggested that full-fat milk and fermented milk further delayed gastric emptying compared with semiskimmed milk in favour of glycaemic regulation. Similarly, Schneeman et al. ${ }^{(196)}$ showed that there were greater CCK responses after the ingestion of a dairy relative to non-dairy fat source or a high-fat meal (38\% of energy) compared with a low-fat meal (20\%), although that was not related to greater satiety. However, any inhibitory effect of dairy fat consumption on appetite and consequently bodyweight regulation may be inconsequential when the higher energy intake that whole milk products provide is considered.

Effects of calcium. Whether Ca plays a role in the regulation of food intake remains to be determined. The idea of a Ca-specific appetite control was first proposed by Tordoff ${ }^{(197)}$ who suggested that low concentrations of $\mathrm{Ca}$ in the diets may promote a desire to eat or choose foods rich in $\mathrm{Ca}$ content. A number of studies conducted in rodents support the hypothesis ${ }^{(198-200)}$. Paradis \& Cabanac ${ }^{(199)}$ showed in a 6-week intervention that the Ca-deprived group of rats chose a high- $\mathrm{CaCl}_{2}$ drinking solution whilst the control and $\mathrm{Ca}$ supplemental group of rats chose a low-CaCl 2 solution.

However, in human subjects, only two studies have examined the effect of either dairy or supplementary $\mathrm{Ca}$ on appetite or food choice ${ }^{(131,201)}$. A recent energyrestricted study indicated that $\mathrm{Ca}$ and vitamin $\mathrm{D}$ supplementation enhanced fat loss in women who were low $\mathrm{Ca}(\leq 600 \mathrm{mg} / \mathrm{d})$ consumers $(P<0 \cdot 01)$. The difference in fat and body-weight loss was highly correlated with a reduction in lipid intake at an ad libitum buffet-type lunch, implying that $\mathrm{Ca}$ may influence macronutrient preferences. The authors speculated that since fats and $\mathrm{Ca}$ tend to occur together in many foods, Ca-deficient individuals might inadvertently, but preferentially, choose to consume high-fat foods, such as cheese, as a consequence of this association between nutrients, in order to obtain dietary $\mathrm{Ca}$. In contrast, Lorenzen et al. ${ }^{(131)}$ showed no significant effect of high dairy and supplementary Ca consumption on appetite sensation, on the secretion of appetite-regulator hormones, and on the subsequent energy intake of the ad libitum meal.

Currently there is a lack of a plausible mechanisms linking $\mathrm{Ca}$ with appetite, and a lack of understanding whether any suggested evidence of an association between $\mathrm{Ca}$ deficiency and appetite is due to $\mathrm{Ca}$ or a lack of other dietary components that co-exist in Ca-rich foods. Further studies are warranted to show how and if Ca deficiency, which is commonly observed during energy-restriction diets, can increase hunger, impair compliance and influence weight-loss outcomes.

Evidence of dairy product effects on appetite regulation. There are relatively few studies that have examined the effect of milk or individual milk products as whole foods on appetite and satiety (Table 7$)^{(202-210)}$. To our knowledge, the first study that showed the higher satiety response of yoghurt and cheese compared with similar and energy-matched foods $(1000 \mathrm{~kJ})$ was by Holt et $a l{ }^{(211)}$. Their results indicated that consumption of foods rich in protein, fibre and water content could potentially reduce energy intake and promote weight loss. In a cross-over study ${ }^{(206)}$, where fifty-eight subjects consumed either low (< one serving/d) or high ( $>$ three serving/d) dairy products for $7 \mathrm{~d}$, no significant difference in subjective appetite ratings was evident, although there was an increase in energy intake by $874 \mathrm{~kJ}(P<0.05)$ during the 
Table 7. Studies of dairy consumption and their effect on food intake and appetite

\begin{tabular}{|c|c|c|}
\hline Study & Details & Results and conclusion \\
\hline Soenen \& Westerterp-Plantenga $(2007)^{(202)}$ & $\begin{array}{l}\text { A within-subjects design } \\
\text { Study A: fifteen women and fifteen men } \\
\text { Study B: twenty women and twenty men } \\
\text { Stimuli: } 4 \times 800 \mathrm{ml} \text { drinks containing no energy or } 1.5 \mathrm{MJ} \text { from } \\
\text { sucrose, HFCS or milk }\end{array}$ & $\begin{array}{l}\text { No differences in satiety and energy balance were observed } 50 \text { min after } \\
\text { consumption of HFCS, sucrose or milk preloads; } 170 \% \mathrm{~mm} \text { (AUC) } \\
\text { VAS changes }\end{array}$ \\
\hline Almiron-Roig \& Drewnowski (2003) & $\begin{array}{l}\text { A within-subjects design; fourteen men and eighteen women } \\
\text { Stimuli: orange juice, low-fat milk ( } 1 \%) \text {, regular cola and sparkling } \\
\text { water }\end{array}$ & $\begin{array}{l}\text { The inclusion of orange juice, regular cola and low-fat milk (1\%) with a } \\
\text { lunch showed no significant differences in hunger, satiety and energy } \\
\text { intake in a lunch } 2 \mathrm{~h} \text { after ingestion }\end{array}$ \\
\hline Harper et al. (2007) $)^{(204)}$ & $\begin{array}{l}\text { A randomised cross-over study; twenty-two men } \\
\text { Stimuli: } 500 \mathrm{ml} \text { cola or chocolate milk (900 kJ) was ingested } 30 \mathrm{~min} \\
\text { before an ad libitum lunch }\end{array}$ & $\begin{array}{l}\text { No difference on ad libitum energy intake ( } 3145 \text { (SD } 1268) \mathrm{kJ} \text { and } 3286 \\
\text { (SD 1346) kJ after chocolate milk and cola, respectively) but chocolate } \\
\text { milk resulted in a significantly greater satiety and fullness } 30 \text { min after } \\
\text { their consumption }(P<0.001)\end{array}$ \\
\hline Tsuchiya et al. (2006) $)^{(205)}$ & $\begin{array}{l}\text { A within-subjects design; sixteen men and sixteen women } \\
\text { Stimuli: a semi-solid peach yoghurt }(378 \mathrm{~g}) \text {, the same yoghurt in a } \\
\text { drinkable homogenised form }(378 \mathrm{~g}) \text {, a peach-flavoured dairy } \\
\text { beverage }(400 \mathrm{ml}) \text { and a peach juice beverage }(400 \mathrm{ml})\end{array}$ & $\begin{array}{l}\text { Higher satiety following the two yoghurts (no difference between them) } \\
\text { compared with the beverages and no differences among them were } \\
\text { observed in energy intake } 90 \text { min after their consumption }\end{array}$ \\
\hline Hollis \& Mattes $(2007)^{(206)}$ & $\begin{array}{l}\text { A randomised cross-over study; twenty-eight men and thirty women } \\
\text { Stimuli: one portion of dairy/d or three portions of dairy/d for } 7 \mathrm{~d}\end{array}$ & $\begin{array}{l}\text { No differences on subjective appetite ratings, although energy intake was } \\
\text { increased by } 874 \mathrm{~kJ} / \mathrm{d}(P<0.05) \text { during the high-dairy consumption } \\
\text { period }\end{array}$ \\
\hline Ruijschop et al. (2008) $)^{(207)}$ & $\begin{array}{l}\text { A randomised cross-over study; forty-three women } \\
\text { Stimuli: } 150 \mathrm{ml}, 1.0 \mathrm{MJ} \text { of a fermented dairy beverage, non- } \\
\text { fermented dairy beverage (placebo) and a non-fermented } \\
\text { dairy beverage with } 0.6 \% \mathrm{Ca}\left(\mathrm{C}_{2} \mathrm{H}_{5} \mathrm{OO}\right)_{2}\end{array}$ & $\begin{array}{l}\text { Fermented dairy beverage resulted in higher fullness }(F=4.21 ; P=0.02) \text {, } \\
\text { less hunger }(F=4.49 ; P=0.02) \text { and less desire to eat }(F=5.34 ; \\
P=0.006) \text {. No differences were observed in energy intake } 25 \text { min after } \\
\text { the dairy beverage consumption }\end{array}$ \\
\hline Dove et al. $(2009)^{(208)}$ & $\begin{array}{l}\text { A randomised cross-over study; thirteen men and thirty-four women } \\
\text { Stimuli: a fixed breakfast with either } 600 \mathrm{ml} \text { skimmed milk or } 600 \mathrm{ml} \\
\text { fruit juice }(1062 \mathrm{~kJ}) \text { provided } 4 \mathrm{~h} \text { before an ad libitum lunch }\end{array}$ & $\begin{array}{l}\text { The mean energy intake at lunch was } 2432(95 \% \mathrm{Cl} 2160,2704) \text { and } 2658 \\
(95 \% \mathrm{Cl} 2386,2930) \mathrm{kJ} \text { after consumption of the skimmed milk and fruit } \\
\text { juice, respectively, with the mean difference being } 8.5 \%(P<0.05)\end{array}$ \\
\hline Potier et al. (2009) $)^{(209)}$ & $\begin{array}{l}\text { A within-subjects design; twenty-seven women } \\
\text { Stimuli: a cheesy snack containing } 22 \mathrm{~g} \text { protein (casein) }(836 \mathrm{~kJ}) \text {, } \\
\text { a cheesy snack (whey + casein, } 2: 1)(836 \mathrm{~kJ}) \text { ingested } 60 \mathrm{~min} \\
\text { before an ad libitum lunch }\end{array}$ & $\begin{array}{l}\text { The energy compensation at lunch was } 83.1 \text { (SEM 9.4) and } 67.0 \text { (SEM 16.4) } \\
\% \text { for whey + casein and casein cheese, respectively, and } 121.6 \\
\text { (SEM } 36.5 \text { ) and } 142.1 \text { (SEM } 29.7 \text { ) \% for whey + casein and casein } \\
\text { cheese, respectively, considering the daily energy intake }\end{array}$ \\
\hline Sanggaard et al. (2004) & $\begin{array}{l}\text { A randomised cross-over study; eight men } \\
\text { Stimuli: } 1.4 \text { litres of milk or } 1.4 \text { litres of fermented milk plus } 15 \mathrm{~g} \\
\text { lactose }\end{array}$ & $\begin{array}{l}\text { The gastric emptying was slower after the fermented milk than milk } \\
(P<0.001) \text { probably due to higher viscosity although there were } \\
\text { no significant differences in appetite }\end{array}$ \\
\hline
\end{tabular}

HFCS, high-fructose corn syrup; AUC, area under curve; VAS, visual analogue scale. 
high-dairy consumption period. The intake of dairy protein was between 2.3 and $14.3 \mathrm{~g} / \mathrm{d}$, while in relevant studies that observed a satiating effect of proteins, the intake of protein was between 45 and $50 \mathrm{~g} / \mathrm{d}^{(173,174)}$. Thus, a possible threshold level of dairy protein intake was not reached and in combination with the short intervention time and small sample size may explain the results. Furthermore, whether fermented dairy products have a stronger effect on appetite and satiety than non-fermented dairy remains to be clarified ${ }^{(207,210)}$.

Although in the majority of the above studies no subsequent difference in energy intake at the ad libitum meal was observed, not all of the studies have been primarily powered to detect differences in energy intake. In contrast, two recent studies, with energy intake as their primary outcome, identified differences in energy intake (Table 7) ${ }^{(208,209)}$. Dove et al. ${ }^{(208)}$ showed that satiety was increased and energy intake at the ad libitum lunch decreased $4 \mathrm{~h}$ after the consumption of skimmed milk compared with an isoenergetic fruit drink in overweight men and women. Potier et al. ${ }^{(209)}$ also concluded that the regular consumption of a moderate-energy cheese snack $(836 \mathrm{~kJ})$ would not result in weight gain due to the compensation observed not only at the ad libitum lunch but also on the whole-day energy intake.

Further, longer-term and adequately powered studies are required to investigate if habitual dairy product consumption has an effect on appetite regulation and, as a consequence, subsequent energy intake.

\section{Conclusions}

The incidence of obesity is increasing dramatically worldwide. Dairy products are an integral part of the Western diet. There is accumulating epidemiological data based on cross-sectional (five studies) and particularly prospective studies (seven studies) that show a modest but significant inverse association between dairy product consumption and body-weight gain. Only one study has reported weight gain with consumption of dairy products, indicating that dairy foods can be consumed as a major source of nutrients during weight maintenance. Evidence from intervention studies not involving energy intake restriction is inconsistent regarding body-weight change (Table 8), although nine studies out of twelve showed no effect of dairy consumption specifically on weight loss. During energy restriction, the data are also still inconsistent. The interpretation of the relevant evidence is complicated by the ability of humans to regulate energy intake. Future studies that examine the relationship between dairy products and body composition should use dairy consumption both with and without adjustment for energy intake. There is currently a paucity of evidence regarding the impact of the type of dairy product on the association between dairy consumption and body composition.

Considering $\mathrm{Ca}$, numerous epidemiological studies and especially intervention trials with energy restriction strongly support that dietary $\mathrm{Ca}$ is negatively associated with measures of adiposity, highlighting its potential beneficial effects as a component of weight-loss treatments in overweight and obese individuals, in particular individuals with a low habitual Ca intake $(<700 \mathrm{mg} / \mathrm{d})$ (Table 8). A greater effect of dairy Ca than the supplemental form is suggestive that dairy bioactive components other than Ca may also be involved.

Numerous plausible mechanisms underlying the beneficial effect of dairy products on body-weight regulation have been proposed. Currently the greatest strength of evidence is available for $\mathrm{Ca}$ as a principal bioactive

Table 8. Studies that examined the association between dairy product consumption and dietary calcium* and measures of body composition

\begin{tabular}{|c|c|}
\hline References & Main conclusions \\
\hline \multicolumn{2}{|l|}{ Cross-sectional studies } \\
\hline $24,25,27,28,32,33^{\star}, 35^{\star}, 36^{\star}, 37^{\star}, 38^{\star}, 39^{\star}$ & Inverse association between dairy products and measures of body composition \\
\hline \multicolumn{2}{|l|}{$40^{\star}, 41^{\star}, 42^{\star}, 43^{\star}, 44^{\star}, 47^{\star}, 49^{\star}$} \\
\hline $26,29,30,45^{\star}, 46^{\star}$ & No association \\
\hline $34,48^{*}$ & Positive association \\
\hline \multicolumn{2}{|c|}{ Prospective studies examined in a cross-sectional manner } \\
\hline $27,50^{\star}, 51^{*}, 52^{\star}, 54,57^{\star}, 58,59,62^{\star}, 65^{\star}$ & Inverse association between dairy products and measures of body composition \\
\hline $50,53^{\star}, 56,64^{\star}$ & No association \\
\hline $55,56,60,61$ & Positive association \\
\hline \multicolumn{2}{|l|}{ Prospective studies } \\
\hline $67,68,69,70,71,73,74$ & Inverse association between dairy products and measures of body composition \\
\hline $72,75,76^{*}$ & No association \\
\hline \multicolumn{2}{|l|}{ Intervention trials } \\
\hline \multicolumn{2}{|l|}{ Without energy restriction } \\
\hline 87,89 & Inverse association between dairy products and measures of body composition \\
\hline $81-86,88,90,100$ & No association \\
\hline 79,80 & Positive association \\
\hline \multicolumn{2}{|l|}{ With energy restriction } \\
\hline $88,91,94,95^{\star}, 96^{\star}, 97^{\star}, 98^{\star}$ & Inverse association between dairy products and measures of body composition \\
\hline $77,92,93,99$ & No association \\
\hline
\end{tabular}

* Studies that examined dietary $\mathrm{Ca}$. 
component with a proposed effect on adipocyte lipid metabolism, lipogenesis and lipolysis, fat oxidation and fat absorption. Additionally, dairy constituents such as lactose, protein (in particular whey proteins) and their peptide derivatives may have an effect on body weight through the regulation of food intake and appetite. Although the impact of individual dairy constituents on food intake and appetite has been investigated to some degree, there is a paucity of evidence from well-designed intervention studies that examine the impact of dairy product consumption, as whole foods, or the effect of individual products on appetite and overall energy intake.

In conclusion, epidemiological data support the notion of a benefit of dairy product consumption for weight maintenance. However, there is an urgent need for welldesigned, long-term randomised intervention studies, with adequate replication and with body-weight changes and measures of adiposity as their primary outcomes, in order to verify the potential benefits of specific dairy products on weight regulation and weight and fat loss and provide an insight into the underlying physiological mechanisms.

\section{Acknowledgements}

The present review article was funding by the Barham Benevolent Trust Studentship and DairyCo UK.

A. D. drafted the manuscript. All authors contributed to, and approved, the final version of the manuscript.

There are no conflicts of interest.

\section{References}

1. Department of Health (1991) Dietary Reference Values for Food Energy amd Nutrients for the UK: Report on Health and Social Subjects. no. 41. London: H.M. Stationery Office.

2. World Health Organization (2010) Obesity and Overweight. http://www.who.int/dietphysicalactivity/publications/facts/ obesity/en/ (accessed 13 October 2008).

3. World Health Organization (2010) WHO Global Infobase: Data For Saving Lives. http://www.who.int/infobase/ report.aspx?rid=118 (accessed 13 October 2008).

4. Department for Environment, Food and Rural Affairs (2007) Desktop Study into Demand for Dairy Products. http://www.defra.gov.uk/foodfarm/food/industry/sectors/ milk/pdf/agraceasreport.pdf (accessed 20 October 2008).

5. International Dairy Federation (2007) The World Dairy Situation 2007. Bulletin of the International Dairy Federation no. 423/2007. London: UK-IDF.

6. Milk Development Council (2010) Dairy consumption. http://www.dairyco.org.uk/datum/consumer/uk-dairy-con sumption/uk-dairy-consumption.aspx (accessed 20 October 2008).

7. Gould BW (2010) Understanding Dairy Markets. http://future. aae.wisc.edu/tab/sales.html\#53 (accessed 24 July 2009).

8. Canadian Dairy Information Centre (2010) Consumption of dairy products. http://www.dairyinfo.gc.ca/index_e.php? $\mathrm{s} 1=\mathrm{dff}-\mathrm{fcil} \& \mathrm{~s} 2=\mathrm{cons} \& \mathrm{~s} 3=\mathrm{cons}($ accessed 24 July 2009$)$.

9. Kearney J (2010) Food consumption trends and drivers. Philos Trans R Soc Lond B Biol Sci 365, 2793-2807.
10. Flynn A, Hirvonen T, Mensink GB, et al. (2009) Intake of selected nutrients from foods, from fortification and from supplements in various European countries. Food Nutr Res 53, (epublication 5 October 2009).

11. Pfeuffer M \& Schrezenmeir J (2007) Milk and the metabolic syndrome. Obesity Rev 8, 109-118.

12. Van Meijl LE, Vrolix R \& Mensink RP (2008) Dairy product consumption and the metabolic syndrome. Nutr Res Rev 21, 148-157.

13. Barr SI (2003) Increased dairy product or calcium intake: is body weight or composition affected in humans? J Nutr 133, 245S-248S.

14. Trowman R, Dumville JC, Hahn S, et al. (2006) A systematic review of the effects of calcium supplementation on body weight. BrJ Nutr 95, 1033-1038.

15. Winzenberg T, Shaw K, Fryer J, et al. (2007) Calcium supplements in healthy children do not affect weight gain, height, or body composition. Obesity 15, 1789-1798.

16. Elwood PC, Hughes J \& Fehily AM (2005) Milk, heart disease and obesity: an examination of the evidence. $\mathrm{BrJ}$ Cardiol 12, 283-290.

17. Schrager S (2005) Dietary calcium intake and obesity. $J$ Am Board Fam Pract 18, 205-210.

18. Teegarden D (2005) The influence of dairy product consumption on body composition. J Nutr 135, 2749-2752.

19. Barba G \& Russo P (2006) Dairy foods, dietary calcium and obesity: a short review of the evidence. Nutr Metab Cardiovasc Dis 16, 445-451.

20. Major GC, Chaput JP, Ledoux M, et al. (2008) Recent developments in calcium-related obesity research. Obes Rev $\mathbf{9}$, 428-445.

21. Parikh SJ \& Yanovski JA (2003) Calcium intake and adiposity. Am J Clin Nutr 77, 281-287.

22. Lanou AJ \& Barnard ND (2008) Dairy and weight loss hypothesis: an evaluation of the clinical trials. Nutr Rev 66, 272-279.

23. Willett WC, Howe GR \& Kushi LH (1997) Adjustment for total energy intake in epidemiologic studies. Am J Clin Nutr 65, 1220S-1231S

24. Mirmiran P, Esmaillzadeh A \& Azizi F (2005) Dairy consumption and body mass index: an inverse relationship. Int J Obes (Lond) 29, 115-121.

25. Varenna M, Binelli L, Casari S, et al. (2007) Effects of dietary calcium intake on body weight and prevalence of osteoporosis in early postmenopausal women. Am J Clin Nutr 86, 639-644.

26. Murakami K, Okubo H \& Sasaki S (2006) No relation between intakes of calcium and dairy products and body mass index in Japanese women aged 18 to 20 y. Nutrition 22, 490-495.

27. Azadbakht L, Mirmiran P, Esmaillzadeh A, et al. (2005) Dairy consumption is inversely associated with the prevalence of the metabolic syndrome in Tehranian adults. Am J Clin Nutr 82, 523-530.

28. Azadbakht L \& Esmaillzadeh A (2008) Dietary and nondietary determinants of central adiposity among Tehrani women. Public Health Nutr 11, 528-534.

29. Snijder MB, van der Heijden A, van Dam RM, et al. (2007) Is higher dairy consumption associated with lower body weight and fewer metabolic disturbances? The Hoorn Study. Am J Clin Nutr 85, 989-995.

30. Brooks BM, Rajeshwari R, Nicklas TA, et al. (2006) Association of calcium intake, dairy product consumption with overweight status in young adults (1995-1996): the Bogalusa Heart Study. J Am Coll Nutr 25, 523-532.

31. Beydoun MA, Gary TL, Caballero BH, et al. (2008) Ethnic differences in dairy and related nutrient consumption 
among US adults and their association with obesity, central obesity, and the metabolic syndrome. Am J Clin Nutr 87, $1914-1925$.

32. Marques-Vidal P, Goncalves A \& Dias CM (2006) Milk intake is inversely related to obesity in men and in young women: data from the Portuguese Health Interview Survey 1998-1999. Int J Obes 30, 88-93.

33. Dicker D, Belnic Y, Goldsmith R, et al. (2008) Relationship between dietary calcium intake, body mass index, and waist circumference in MABAT - the Israeli National Health and Nutrition Study. Isr Med Assoc J 10, 512-515.

34. Lawlor DA, Ebrahim S, Timpson N, et al. (2005) Avoiding milk is associated with a reduced risk of insulin resistance and the metabolic syndrome: findings from the British Women's Heart and Health Study. Diabet Med 22, 808-811.

35. McCarron DA, Morris CD, Henry HJ, et al. (1984) Blood pressure and nutrient intake in the United States. Science 224, 1392-1398.

36. Zemel MB, Shi H, Greer B, et al. (2000) Regulation of adiposity by dietary calcium. FASEB J 14, 1132-1138.

37. Heaney RP (2003) Normalizing calcium intake: projected population effects for body weight. J Nutr 133, 268S-270S.

38. Bueno MB, Cesar CL, Martini LA, et al. (2008) Dietary calcium intake and overweight: an epidemiologic view. Nutrition 24, 1110-1115.

39. Heiss CJ, Shaw SE \& Carothers L (2008) Association of calcium intake and adiposity in postmenopausal women. J Am Coll Nutr 27, 260-266.

40. Davies KM, Heaney RP, Recker RR, et al. (2000) Calcium intake and body weight. J Clin Endocrinol Metab 85, 4635-4638.

41. Buchowski MS, Semenya J \& Johnson AO (2002) Dietary calcium intake in lactose maldigesting intolerant and tolerant African-American women. J Am Coll Nutr 21, $47-54$.

42. Rosell M, Johansson G, Berglund L, et al. (2004) Associations between the intake of dairy fat and calcium and abdominal obesity. Int J Obes Relat Metab Disord 28, 1427-1434.

43. Loos RJF, Rankinen T, Leon AS, et al. (2004) Calcium intake is associated with adiposity in black and white men and white women of the HERITAGE Family Study. J Nutr 134, 1772-1778.

44. Lovejoy JC, Champagne CM, Smith SR, et al. (2001) Ethnic differences in dietary intakes, physical activity, and energy expenditure in middle-aged, premenopausal women: the Healthy Transitions Study. Am J Clin Nutr 74, 90-95.

45. Eilat-Adar S, Xu JQ, Loria C, et al. (2007) Dietary calcium is associated with body mass index and body fat in American Indians. J Nutr 137, 1955-1960.

46. Venti CA, Tataranni PA \& Salbe AD (2005) Lack of relationship between calcium intake and body size in an obesity-prone population. J Am Diet Assoc 105, 1401-1407.

47. Jacqmain M, Doucet E, Després JP, et al. (2003) Calcium intake, body composition, and lipoprotein-lipid concentrations in adults. Am J Clin Nutr 77, 1448-1452.

48. Kamycheva E, Joakimsen RM \& Jorde R (2003) Intakes of calcium and vitamin $\mathrm{D}$ predict body mass index in the population of northern Norway. J Nutr 133, 102-106.

49. Kruger HS, Rautenbach PH, Venter CS, et al. (2007) An inverse association between calcium and adiposity in women with high fat and calcium intakes. Ethn Dis 17, $6-13$.

50. Ness AR, Smith GD \& Hart C (2001) Milk, coronary heart disease and mortality. J Epidemiol Community Health 55, 379-382.
51. Van der Vijver LPL, van der Waal MAE, Weterings KGC, et al. (1992) Calcium intake and 28-year cardiovascular and coronary heart-disease mortality in Dutch civil-servants. Int J Epidemiol 21, 36-39.

52. Bostick RM, Kushi LH, Wu Y, et al. (1999) Relation of calcium, vitamin $\mathrm{D}$, and dairy food intake to ischemic heart disease mortality among postmenopausal women. Am J Epidemiol 149, 151-161.

53. Iso H, Stampfer MJ, Manson JE, et al. (1999) Prospective study of calcium, potassium, and magnesium intake and risk of stroke in women. Stroke 30, 1772-1779.

54. Elwood PC, Pickering JE, Fehily AM, et al. (2004) Milk drinking, ischaemic heart disease and ischaemic stroke I. Evidence from the Caerphilly cohort. Eur J Clin Nutr 58, $711-717$.

55. Liu SM, Choi HK, Ford E, et al. (2006) A prospective study of dairy intake and the risk of type 2 diabetes in women. Diabetes Care 29, 1579-1584.

56. Choi HK, Willett WC, Stampfer MJ, et al. (2005) Dairy consumption and risk of type 2 diabetes mellitus in men: a prospective study. Arch Intern Med 165, 997-1003.

57. Abbott RD, Curb JD, Rodriguez BL, et al. (1996) Effect of dietary calcium and milk consumption on risk of thromboembolic stroke in older middle-aged men. The Honolulu Heart Program. Stroke 27, 813-818.

58. Alonso A, Beunza JJ, Delgado-Rodriguez M, et al. (2005) Low-fat dairy consumption and reduced risk of hypertension: the Seguimiento Universidad de Navarra (SUN) cohort. Am J Clin Nutr 82, 972-979.

59. Engberink MF, Geleijnse JM, de Jong N, et al. (2009) Dairy intake, blood pressure, and incident hypertension in a general Dutch population. J Nutr 139, 582-587.

60. Engberink MF, Hendriksen MA, Schouten EG, et al. (2009) Inverse association between dairy intake and hypertension: the Rotterdam Study. Am J Clin Nutr 89, 1877-1883.

61. Toledo E, Delgado-Rodríguez M, Estruch R, et al. (2009) Low-fat dairy products and blood pressure: follow-up of 2290 older persons at high cardiovascular risk participating in the PREDIMED study. BrJ Nutr 101, 59-67.

62. Umesawa M, Iso H, Ishihara J, et al. (2008) Dietary calcium intake and risks of stroke, its subtypes, and coronary heart disease in Japanese: the JPHC Study Cohort I. Stroke 39, 2449-2456.

63. Umesawa M, Iso H, Date C, et al. (2006) Dietary intake of calcium in relation to mortality from cardiovascular disease: the JACC Study. Stroke 37, 20-26.

64. van Dam RM, Hu FB, Rosenberg L, et al. (2006) Dietary calcium and magnesium, major food sources, and risk of type 2 diabetes in U.S. black women. Diabetes Care 29, 2238-2243.

65. Liu S, Song Y, Ford ES, et al. (2005) Dietary calcium, vitamin $\mathrm{D}$, and the prevalence of metabolic syndrome in middle-aged and older US women. Diabetes Care 28, 2926-2932.

66. Al-Delaimy WK, Rimm E, Willett WC, et al. (2003) A prospective study of calcium intake from diet and supplements and risk of ischemic heart disease among men. Am J Clin Nutr 77, 814-818.

67. Newby P, Muller D, Hallfrisch J, et al. (2003) Dietary patterns and changes in body mass index and waist circumference in adults. Am J Clin Nutr 77, 1417-1425.

68. Newby PK, Muller D, Hallfrisch J, et al. (2004) Food patterns measured by factor analysis and anthropometric changes in adults. Am J Clin Nutr 80, 504-513.

69. Drapeau V, Despres JP, Bouchard C, et al. (2004) Modifications in food-group consumption are related to long-term body-weight changes. Am J Clin Nutr 80, 29-37. 
70. Pereira MA, Jacobs DR, Van Horn L, et al. (2002) Dairy consumption, obesity, and the insulin resistance syndrome in young adults - The CARDIA study. JAMA 287, 2081-2089.

71. Lutsey PL, Steffen LM \& Stevens J (2008) Dietary intake and the development of the metabolic syndrome: the Atherosclerosis Risk in Communities study. Circulation 117, $754-761$.

72. Rajpathak SN, Rimm EB, Rosner B, et al. (2006) Calcium and dairy intakes in relation to long-term weight gain in US men. Am J Clin Nutr 83, 559-566.

73. Rosell M, Hakansson NN \& Wolk A (2006) Association between dairy food consumption and weight change over 9 y in 19352 perimenopausal women. Am J Clin Nutr 84, $1481-1488$.

74. Vergnaud AC, Peneau S, Chat-Yung S, et al. (2008) Dairy consumption and 6-y changes in body weight and waist circumference in middle-aged French adults. Am J Clin Nutr $\mathbf{8 8}, 1248-1255$.

75. Snijder MB, van Dam RM, Stehouwer CD, et al. (2008) A prospective study of dairy consumption in relation to changes in metabolic risk factors: the Hoorn Study. Obesity (Silver Spring) 16, 706-709.

76. Boon N, Koppes LLJ, Saris WHM, et al. (2005) The relation between calcium intake and body composition in a Dutch population. The Amsterdam Growth and Health Longitudinal Study. Am J Epidemiol 162, 27-32.

77. Thompson WG, Holdman NR, Janzow DJ, et al. (2005) Effect of energy-reduced diets high in dairy products and fiber on weight loss in obese adults. Obes Res 13, 1344-1353.

78. St-Pierre NR (2001) Invited review: Integrating quantitative findings from multiple studies using mixed model methodology. J Dairy Sci 84, 741-755.

79. Barr SI, McCarron DA, Heaney RP, et al. (2000) Effects of increased consumption of fluid milk on energy and nutrient intake, body weight, and cardiovascular risk factors in healthy older adults. J Am Diet Assoc 100, 810-817.

80. Lau EMC, Woo J, Lam V, et al. (2001) Milk supplementation of the diet of postmenopausal Chinese women on a low calcium intake retards bone loss. J Bone Miner Res 16, $1704-1709$

81. Chee WS, Suriah AR, Chan SP, et al. (2003) The effect of milk supplementation on bone mineral density in postmenopausal Chinese women in Malaysia. Osteoporos Int 14 $828-834$.

82. Wong SY, Lau EM, Lau WW, et al. (2004) Is dietary counselling effective in increasing dietary calcium, protein and energy intake in patients with osteoporotic fractures? A randomized controlled clinical trial. I Hum Nutr Diet 17, 359-364.

83. Cleghorn DB, O'Loughlin PD, Schroeder BJ, et al. (2001) An open, crossover trial of calcium-fortified milk in prevention of early postmenopausal bone loss. Med J Aust 175, 242-245.

84. Baran D, Sorensen A, Grimes J, et al. (1990) Dietary modification with dairy products for preventing vertebral bone loss in premenopausal women: a three-year prospective study. J Clin Endocrinol Metab 70, 264-270.

85. Nowson CA, Worsley A, Margerison C, et al. (2005) Blood pressure change with weight loss is affected by diet type in men. Am J Clin Nutr 81, 983-989.

86. Gunther CW, Legowski PA, Lyle RM, et al. (2005) Dairy products do not lead to alterations in body weight or fat mass in young women in a $1-y$ intervention. Am J Clin Nutr 81, 751-756.

87. Eagan MS, Lyle RM, Gunther CW, et al. (2006) Effect of 1 -year dairy product intervention on fat mass in young women: 6-month follow-up. Obesity 14, 2242-2248.
88. Zemel MB, Richards J, Milstead A, et al. (2005) Effects of calcium and dairy on body composition and weight loss in African-American adults. Obes Res 13, 1218-1225.

89. Zemel MB, Donnelly JE, Smith BK, et al. (2008) Effects of dairy intake on weight maintenance. Nutr Metab (Lond) 5, 28.

90. Wennersberg MH, Smedman A, Turpeinen AM, et al. (2009) Dairy products and metabolic effects in overweight men and women: results from a 6-mo intervention study. Am J Clin Nutr 90, 960-968.

91. Zemel MB, Richards J, Mathis S, et al. (2005) Dairy augmentation of total and central fat loss in obese subjects. Int J Obes (Lond) 29, 391-397.

92. Harvey-Berino J, Gold BC, Lauber R, et al. (2005) The impact of calcium and dairy product consumption on weight loss. Obes Res 13, 1720-1726.

93. Bowen J, Noakes M \& Clifton PM (2004) A high dairy protein, high-calcium diet minimizes bone turnover in overweight adults during weight loss. J Nutr 134, 568-573.

94. Zemel MB, Thompson W, Milstead A, et al. (2004) Calcium and dairy acceleration of weight and fat loss during energy restriction in obese adults. Obes Res 12, 582-590.

95. Ochner CN \& Lowe MR (2007) Self-reported changes in dietary calcium and energy intake predict weight regain following a weight loss diet in obese women. J Nutr 137, 2324-2328.

96. Shahar DR, Abel R, Elhayany A, et al. (2007) Does dairy calcium intake enhance weight loss among overweight diabetic patients? Diabetes Care 30, 485-489.

97. Lin YC, Lyle RM, McCabe LD, et al. (2000) Dairy calcium is related to changes in body composition during a two-year exercise intervention in young women. J Am Coll Nutr 19, 754-760.

98. Bailey BW, Sullivan DK, Kirk EP, et al. (2007) The influence of calcium consumption on weight and fat following 9 months of exercise in men and women. J Am Coll Nutr 26, 350-355.

99. Zemel MB, Teegarden D, Van Loan M, et al. (2009) Dairyrich diets augment fat loss on an energy-restricted diet: a multicenter trial. Nutrients 1, 83-100.

100. Manios Y, Moschonis G, Koutsikas K, et al. (2009) Changes in body composition following a dietary and lifestyle intervention trial: the Postmenopausal Health Study. Maturitas 62, 58-65.

101. Vaskonen $T$ (2003) Dietary minerals and modification of cardiovascular risk factors. J Nutr Biochem 14, 492-506.

102. Xue B, Moustaid-Moussa N, Wilkison WO, et al. (1998) The agouti gene product inhibits lipolysis in human adipocytes via a $\mathrm{Ca}^{2+}$-dependent mechanism. FASEB J 12, $1391-1396$.

103. Zemel MB (2002) Regulation of adiposity and obesity risk by dietary calcium: mechanisms and implications. I Am Coll Nutr 21, 146S-151S.

104. Zemel MB (2003) Mechanisms of dairy modulation of adiposity. J Nutr 133, 252S-256S.

105. Zemel MB (2004) Role of calcium and dairy products in energy partitioning and weight management. Am J Clin Nutr 79, 907-912.

106. Shi H, Norman AW, Okamura WH, et al. (2002) $1 \alpha, 25-$ Dihydroxyvitamin $\mathrm{D}_{3}$ inhibits uncoupling protein 2 expression in human adipocytes. FASEB J 16, 1808-1810.

107. Parra P, Bruni G, Palou A, et al. (2008) Dietary calcium attenuation of body fat gain during high-fat feeding in mice. J Nutr Biochem 19, 109-117.

108. Boon N, Hul GB, Stegen JH, et al. (2007) An intervention study of the effects of calcium intake on faecal fat excretion, energy metabolism and adipose tissue mRNA expression 
of lipid-metabolism related proteins. Int J Obes (Lond) $\mathbf{3 1}$, $1704-1712$.

109. Cummings NK, James AP \& Soares MJ (2006) The acute effects of different sources of dietary calcium on postprandial energy metabolism. BrJ Nutr 96, 138-144.

110. Zemel MB \& Sun X (2008) Calcitriol and energy metabolism. Nutr Rev 66, S139-S146.

111. Sun X \& Zemel MB (2004) Role of uncoupling protein 2 (UCP2) expression and $1 \alpha, 25$-dihydroxyvitamin $\mathrm{D}_{3}$ in modulating adipocyte apoptosis. FASEB J 18, 1430-1432.

112. Morris KL \& Zemel MB (2005) 1,25-Dihydroxyvitamin $\mathrm{D}_{3}$ modulation of adipocyte glucocorticoid function. Obes Res 13, 670-677.

113. Sun X, Morris KL \& Zemel MB (2008) Role of calcitriol and cortisol on human adipocyte proliferation and oxidative and inflammatory stress: a microarray study. $J$ Nutrigenet Nutrigenomics 1, 30-48.

114. Sun X \& Zemel MB (2008) Calcitriol and calcium regulate cytokine production and adipocyte-macrophage crosstalk. J Nutr Biochem 19, 392-399.

115. Boon N, Hul GBJ, Viguerie N, et al. (2005) Effects of 3 diets with various calcium contents on 24-h energy expenditure, fat oxidation, and adipose tissue message RNA expression of lipid metabolism-related proteins. Am J Clin Nutr 82, $1244-1252$.

116. Bortolotti M, Rudelle S, Schneiter P, et al. (2008) Dairy calcium supplementation in overweight or obese persons: its effect on markers of fat metabolism. Am J Clin Nutr 88, 877-885.

117. Parikh SJ, Edelman M, Uwaifo GI, et al. (2004) The relationship between obesity and serum 1,25-dihydroxy vitamin D concentrations in healthy adults. J Clin Endocrinol Metab 89, 1196-1199.

118. Yanoff LB, Parikh SJ, Spitalnik A, et al. (2006) The prevalence of hypovitaminosis D and secondary hyperparathyroidism in obese black Americans. Clin Endocrinol (Oxf) 64, 523-529.

119. Melanson EL, Sharp TA, Schneider J, et al. (2003) Relation between calcium intake and fat oxidation in adult humans. Int J Obes 27, 196-203.

120. Skov AR, Toubro S, Ronn B, et al. (1999) Randomized trial on protein vs carbohydrate in ad libitum fat reduced diet for the treatment of obesity. Int J Obes 23, 528-536.

121. Halton TL \& Hu FB (2004) The effects of high protein diets on thermogenesis, satiety and weight loss: a critical review. J Am Coll Nutr 23, 373-385.

122. Melanson EL, Donahoo WT, Dong F, et al. (2005) Effect of low- and high-calcium dairy-based diets on macronutrient oxidation in humans. Obes Res 13, 2102-2112.

123. Gunther CW, Lyle RM, Legowski PA, et al. (2005) Fat oxidation and its relation to serum parathyroid hormone in young women enrolled in a 1-y dairy calcium intervention. Am J Clin Nutr 82, 1228-1234.

124. Jacobsen R, Lorenzen JK, Toubro S, et al. (2005) Effect of short-term high dietary calcium intake on 24-h energy expenditure, fat oxidation, and fecal fat excretion. Int $J$ Obes 29, 292-301.

125. Teegarden D, White KM, Lyle RM, et al. (2008) Calcium and dairy product modulation of lipid utilization and energy expenditure. Obesity (Silver Spring) 16, 1566-1572.

126. Denke MA, Fox MM \& Schulte MC (1993) Short-term dietary calcium fortification increases fecal saturated fat content and reduces serum lipids in men. J Nutr 123, 1047-1053.

127. Shahkhalili Y, Murset C, Meirim I, et al. (2001) Calcium supplementation of chocolate: effect on cocoa butter digestibility and blood lipids in humans. Am J Clin Nutr 73, 246-252.
128. Welberg JW, Monkelbaan JF, de Vries EG, et al. (1994) Effects of supplemental dietary calcium on quantitative and qualitative fecal fat excretion in man. Ann Nutr Metab 38, 185-191.

129. Bendsen NT, Hother AL, Jensen SK, et al. (2008) Effect of dairy calcium on fecal fat excretion: a randomized crossover trial. Int J Obes (Lond) 32, 1816-1824.

130. Christensen R, Lorenzen JK, Svith CR, et al. (2009) Effect of calcium from dairy and dietary supplements on faecal fat excretion: a meta-analysis of randomized controlled trials Obes Rev 10, 475-486.

131. Lorenzen JK, Nielsen S, Holst JJ, et al. (2007) Effect of dairy calcium or supplementary calcium intake on postprandial fat metabolism, appetite, and subsequent energy intake. Am J Clin Nutr 85, 678-687.

132. Govers MJ \& Van der Meet R (1993) Effects of dietary calcium and phosphate on the intestinal interactions between calcium, phosphate, fatty acids, and bile acids. Gut 34, 365-370.

133. Zemel MB, Teegarden D, Van Loan M, et al. (2004) Role of dairy products in modulating weight and fat loss: a multicenter trial. FASEB J 18, 566.5, (Abstr).

134. Terpstra AH (2004) Effect of conjugated linoleic acid on body composition and plasma lipids in humans: an overview of the literature. Am J Clin Nutr 79, 352-361

135. Silveira MB, Carraro R, Monereo S, et al. (2007) Conjugated linoleic acid (CLA) and obesity. Public Health Nutr 10 , $1181-1186$.

136. Plourde M, Jew S, Cunnane SC, et al. (2008) Conjugated linoleic acids: why the discrepancy between animal and human studies? Nutr Rev 66, 415-421.

137. Li JJ, Huang CJ \& Xie D (2008) Anti-obesity effects of conjugated linoleic acid, docosahexaenoic acid, and eicosapentaenoic acid. Mol Nutr Food Res 52, 631-645.

138. Wang YW \& Jones PJ (2004) Conjugated linoleic acid and obesity control: efficacy and mechanisms. Int J Obes Relat Metab Disord 28, 941-955.

139. Marten B, Pfeuffer M \& Schrezenmeir J (2006) Mediumchain triglycerides. Int Dairy J 16, 1374-1382.

140. Moussavi N, Gavino V \& Receveur O (2008) Could the quality of dietary fat, and not just its quantity, be related to risk of obesity? Obesity (Silver Spring) 16, 7-15.

141. St-Onge MP \& Bosarge A (2008) Weight-loss diet that includes consumption of medium-chain triacylglycerol oil leads to a greater rate of weight and fat mass loss than does olive oil. Am J Clin Nutr 87, 621-626.

142. Nagao K \& Yanagita T (2008) Bioactive lipids in metabolic syndrome. Prog Lipid Res 47, 127-146.

143. Tsuji H, Kasai M, Takeuchi H, et al. (2001) Dietary mediumchain triacylglycerols suppress accumulation of body fat in a double-blind, controlled trial in healthy men and women. J Nutr 131, 2853-2859.

144. Nosaka N, Maki H, Suzuki Y, et al. (2003) Effects of margarine containing medium-chain triacylglycerols on body fat reduction in humans. $J$ Atheroscler Thromb 10, 290-298.

145. Dulloo AG, Fathi M, Mensi N, et al. (1996) Twenty-fourhour energy expenditure and urinary catecholamines of humans consuming low-to-moderate amounts of medium-chain triglycerides: a dose-response study in a human respiratory chamber. Eur J Clin Nutr 50, $152-158$.

146. Aoyama T, Nosaka N \& Kasai M (2007) Research on the nutritional characteristics of medium-chain fatty acids. J Med Invest 54, 385-388.

147. Cock TA, Houten SM \& Auwerx J (2004) Peroxisome proliferator-activated receptor-147. 
148. Zemel MB (2005) The role of dairy foods in weight management. J Am Coll Nutr 24, 537S-546S.

149. Westphal S, Kastner S, Taneva E, et al. (2004) Postprandial lipid and carbohydrate responses after the ingestion of a casein-enriched mixed meal. Am J Clin Nutr 80, 284-290.

150. Huth PJ, DiRienzo DB \& Miller GD (2006) Major scientific advances with dairy foods in nutrition and health. J Dairy Sci 89, 1207-1221.

151. Nilsson M, Holst JJ \& Bjorck IM (2007) Metabolic effects of amino acid mixtures and whey protein in healthy subjects: studies using glucose-equivalent drinks. Am J Clin Nutr 85, 996-1004.

152. Layman DK, Shiue H \& Sather C (2003) Increased dietary protein modifies glucose and insulin homeostasis in adult women during weight loss. J Nutr 133, 405-410.

153. Layman DK \& Walker DA (2006) Potential importance of leucine in treatment of obesity and the metabolic syndrome. J Nutr 136, 319S-323S.

154. Anderson GH \& Aziz A (2006) Multifunctional roles of dietary proteins in the regulation of metabolism and food intake: application to feeding infants. J Pediatr 149, S74-S79.

155. Schwartz MW, Woods SC, Porte D Jr, et al. (2000) Central nervous system control of food intake. Nature $\mathbf{4 0 4}$, 661-671.

156. Cummings DE \& Overduin J (2007) Gastrointestinal regulation of food intake. J Clin Invest 117, 13-23.

157. Wynne K, Stanley S, McGowan B, et al. (2005) Appetite control. J Endocrinol 184, 291-318.

158. Badman MK \& Flier JS (2005) The gut and energy balance: visceral allies in the obesity wars. Science 307, 1909-1914.

159. Biddinger SB \& Kahn CR (2006) From mice to men: insights into the insulin resistance syndromes. Annu Rev Physiol 68, $123-158$

160. Munzberg H \& Myers MG Jr (2005) Molecular and anatomical determinants of central leptin resistance. Nat Neurosci 8, 566-570.

161. Cummings DE (2006) Ghrelin and the short- and long-term regulation of appetite and body weight. Physiol Behav 89, $71-84$.

162. de Graaf C, Blom WA, Smeets PA, et al. (2004) Biomarkers of satiation and satiety. Am J Clin Nutr 79, 946-961.

163. Naslund E \& Hellstrom PM (2007) Appetite signaling: from gut peptides and enteric nerves to brain. Physiol Behav 92, $256-262$

164. Coll AP, Farooqi IS \& O'Rahilly S (2007) The hormonal control of food intake. Cell 129, 251-262.

165. Murphy KG \& Bloom SR (2006) Gut hormones and the regulation of energy homeostasis. Nature 444, 854-859.

166. Aziz GAA (2007) The effects of dairy components on food intake and satiety. In Functional Dairy Products, pp. 19-45 [M Saarela, editor]. Cambridge: Woodhead Publishing Limited.

167. Morton GJ, Cummings DE, Baskin DG, et al. (2006) Central nervous system control of food intake and body weight. Nature 443, 289-295.

168. Flint A, Gregersen NT, Gluud LL, et al. (2007) Associations between postprandial insulin and blood glucose responses, appetite sensations and energy intake in normal weight and overweight individuals: a meta-analysis of test meal studies. Br J Nutr 98, 17-25.

169. Veldhorst M, Smeets A, Soenen S, et al. (2008) Proteininduced satiety: effects and mechanisms of different proteins. Physiol Behav 94, 300-307.

170. Batterham RL, Heffron H, Kapoor S, et al. (2006) Critical role for peptide $\mathrm{YY}$ in protein-mediated satiation and body-weight regulation. Cell Metab 4, 223-233.
171. Anderson GH \& Moore SE (2004) Dietary proteins in the regulation of food intake and body weight in humans. J Nutr 134, 974S-979S

172. Etzel MR (2004) Manufacture and use of dairy protein fractions. J Nutr 134, 996S-1002S.

173. Hall WL, Millward DJ, Long SJ, et al. (2003) Casein and whey exert different effects on plasma amino acid profiles, gastrointestinal hormone secretion and appetite. Br J Nutr 89, 239-248.

174. Anderson GH, Tecimer SN, Shah D, et al. (2004) Protein source, quantity, and time of consumption determine the effect of proteins on short-term food intake in young men. J Nutr 134, 3011-3015.

175. Veldhorst MA, Nieuwenhuizen AG, Hochstenbach-Waelen A, et al. (2009) Dose-dependent satiating effect of whey relative to casein or soy. Physiol Behav 96, 675-682.

176. Bowen J, Noakes M, Trenerry C, et al. (2006) Energy intake, ghrelin, and cholecystokinin after different carbohydrate and protein preloads in overweight men. J Clin Endocrinol Metab 91, 1477-1483.

177. Bowen J, Noakes M \& Clifton PM (2006) Appetite regulatory hormone responses to various dietary proteins differ by body mass index status despite similar reductions in ad libitum energy intake. J Clin Endocrinol Metab 91, 2913-2919.

178. Bowen J, Noakes M \& Clifton PM (2007) Appetite hormones and energy intake in obese men after consumption of fructose, glucose and whey protein beverages. Int $J$ Obes (Lond) 31, 1696-1703.

179. Diepvens K, Haberer D \& Westerterp-Plantenga M (2008) Different proteins and biopeptides differently affect satiety and anorexigenic/orexigenic hormones in healthy humans. Int J Obes (Lond) 32, 510-518.

180. Dangin M, Boirie Y, Garcia-Rodenas C, et al. (2001) The digestion rate of protein is an independent regulating factor of postprandial protein retention. Am J Physiol Endocrinol Metab 280, E340-E348.

181. Luhovyy BL, Akhavan T \& Anderson GH (2007) Whey proteins in the regulation of food intake and satiety. $J \mathrm{Am}$ Coll Nutr 26, 704S-712S.

182. Dunshea FR, Ostrowska E, Ferrari JM, et al. (2007) Dairy proteins and the regulation of satiety and obesity. Aust J Exp Agric 47, 1051-1058.

183. Veldhorst MA, Nieuwenhuizen AG, Hochstenbach-Waelen A, et al. (2009) Effects of complete whey-protein breakfasts versus whey without GMP-breakfasts on energy intake and satiety. Appetite 52, 388-395.

184. Anderson GH \& Woodend D (2003) Consumption of sugars and the regulation of short-term satiety and food intake. Am J Clin Nutr 78, 843S-849S.

185. Roberts SB (2000) High-glycemic index foods, hunger, and obesity: is there a connection? Nutr Rev $\mathbf{5 8}$, 163-169.

186. Raben A (2002) Should obese patients be counselled to follow a low-glycaemic index diet? No. Obes Rev 3, $245-256$.

187. Aston LM, Stokes CS \& Jebb SA (2008) No effect of a diet with a reduced glycaemic index on satiety, energy intake and body weight in overweight and obese women. Int J Obes (Lond) 32, 160-165.

188. Arumugam V, Lee JS, Nowak JK, et al. (2008) A highglycemic meal pattern elicited increased subjective appetite sensations in overweight and obese women. Appetite $\mathbf{5 0 ,}$ $215-222$

189. Food Standard Agency (2002) McCance and Widdowson's The Composition of Foods, sixth summary ed. Cambridge: Royal Society of Chemistry. 
190. Blundell JE \& MacDiarmid JI (1997) Fat as a risk factor for overconsumption: satiation, satiety, and patterns of eating. J Am Diet Assoc 97, S63-S69.

191. Noakes M, Bowen J \& Clifton P (2005) Dairy foods or fractions for appetite and weight control. Aust J Dairy Tech 60, 152-153.

192. Feltrin KL, Patterson M, Ghatei MA, et al. (2006) Effect of fatty acid chain length on suppression of ghrelin and stimulation of PYY, GLP-2 and PP secretion in healthy men. Peptides 27, 1638-1643.

193. French S (2004) Effects of dietary fat and carbohydrate on appetite vary depending upon site and structure. Br J Nutr 92, Suppl. 1, S23-S26.

194. Little TJ, Horowitz M \& Feinle-Bisset C (2007) Modulation by high-fat diets of gastrointestinal function and hormones associated with the regulation of energy intake: implications for the pathophysiology of obesity. Am J Clin Nutr 86, 531-541.

195. Haug A, Høstmark AT \& Harstad OM (2007) Bovine milk in human nutrition - a review. Lipids Health Dis 6, 25.

196. Schneeman BO, Burton-Freeman B \& Davis P (2003) Incorporating dairy foods into low and high fat diets increases the postprandial cholecystokinin response in men and women. J Nutr 133, 4124-4128.

197. Tordoff MG (2001) Calcium: taste, intake, and appetite. Physiol Rev 81, 1567-1597.

198. McCaughey SA, Forestell CA \& Tordoff MG (2005) Calcium deprivation increases the palatability of calcium solutions in rats. Physiol Behav 84, 335-342.

199. Paradis S \& Cabanac M (2005) Calcium deficiency cannot induce obesity in rats. Physiol Behav 85, 259-264.

200. Tordoff MG \& Rabusa SH (1998) Calcium-deprived rats avoid sweet compounds. J Nutr 128, 1232-1238.

201. Major GC, Alarie FP, Dore J, et al. (2009) Calcium plus vitamin D supplementation and fat mass loss in female very low-calcium consumers: potential link with a calcium-specific appetite control. Br J Nutr 101, 659-663.

202. Soenen S \& Westerterp-Plantenga MS (2007) No differences in satiety or energy intake after high-fructose corn syrup, sucrose, or milk preloads. Am J Clin Nutr 86, 1586-1594.
203. Almiron-Roig E \& Drewnowski A (2003) Hunger, thirst, and energy intakes following consumption of caloric beverages. Physiol Behav 79, 767-773

204. Harper A, James A, Flint A, et al. (2007) Increased satiety after intake of a chocolate milk drink compared with a carbonated beverage, but no difference in subsequent ad libitum lunch intake. Br J Nutr 97, 579-583.

205. Tsuchiya A, Almiron-Roig E, Lluch A, et al. (2006) Higher satiety ratings following yogurt consumption relative to fruit drink or dairy fruit drink. J Am Diet Assoc 106, 550-557.

206. Hollis JH \& Mattes RD (2007) Effect of increased dairy consumption on appetitive ratings and food intake. Obesity 15, 1520-1526.

207. Ruischop MAJR, Boelrijk EMA \& te Giffel MC (2008) Satiety effects of a dairy beverage fermented with propionic acid bacteria. Int Dairy J 18, 945-950.

208. Dove ER, Hodgson JM, Puddey IB, et al. (2009) Skim milk compared with a fruit drink acutely reduces appetite and energy intake in overweight men and women. Am J Clin Nutr 90, 70-75.

209. Potier M, Fromentin G, Calvez J, et al. (2009) A high-protein, moderate-energy, regular cheesy snack is energetically compensated in human subjects. BrJ Nutr 102, 625-631.

210. Sanggaard KM, Holst JJ, Rehfeld JF, et al. (2004) Different effects of whole milk and a fermented milk with the same fat and lactose content on gastric emptying and postprandial lipaemia, but not on glycaemic response and appetite. Br J Nutr 92, 447-459.

211. Holt SH, Miller JC, Petocz P, et al. (1995) A satiety index of common foods. Eur J Clin Nutr 49, 675-690.

212. Djousse L, Pankow JS, Hunt SC, et al. (2006) Influence of saturated fat and linolenic acid on the association between intake of dairy products and blood pressure. Hypertension 48, 342-348.

213. Wang L, Manson JE, Buring JE, et al. (2008) Dietary intake of dairy products, calcium, and vitamin D and the risk of hypertension in middle-aged and older women. Hypertension 51, 1073-1079.

214. Scholz-Ahrens KE \& Schrezenmeir J (2006) Milk minerals and the metabolic syndrome. Int Dairy J 16, 1399-1407. 